Prepared in cooperation with the Air Force Civil Engineer Center

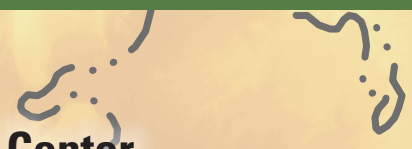

Utilizing Multiple Hydrogeologic and Anthropogenic Indicators to Understand Zones of Groundwater Contribution to Water-Supply Wells Near Kirtland Air Force Base Bulk Fuels Facility in Southeast Albuquerque, New Mexico
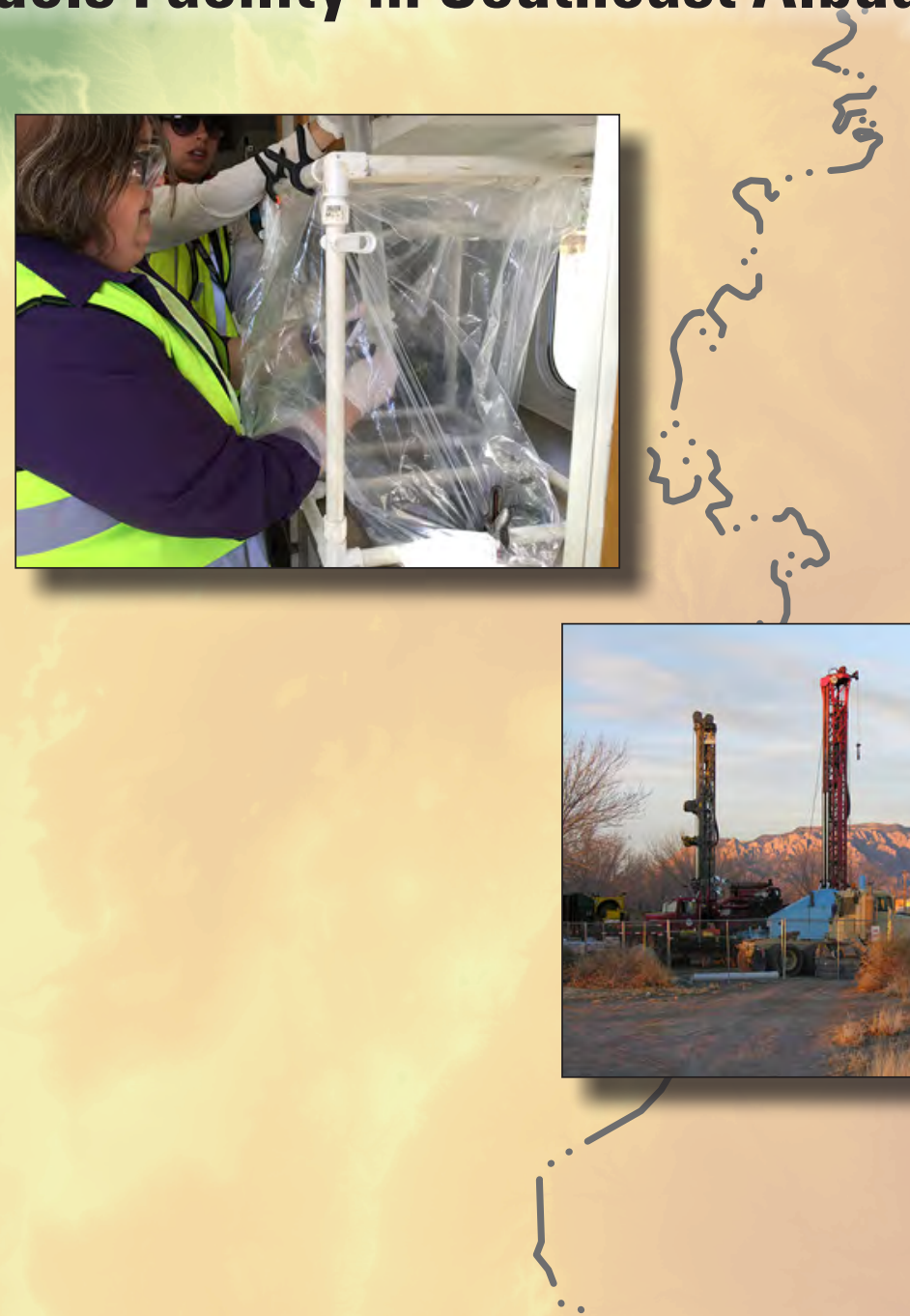

Scientific Investigations Repprt 2021-5076

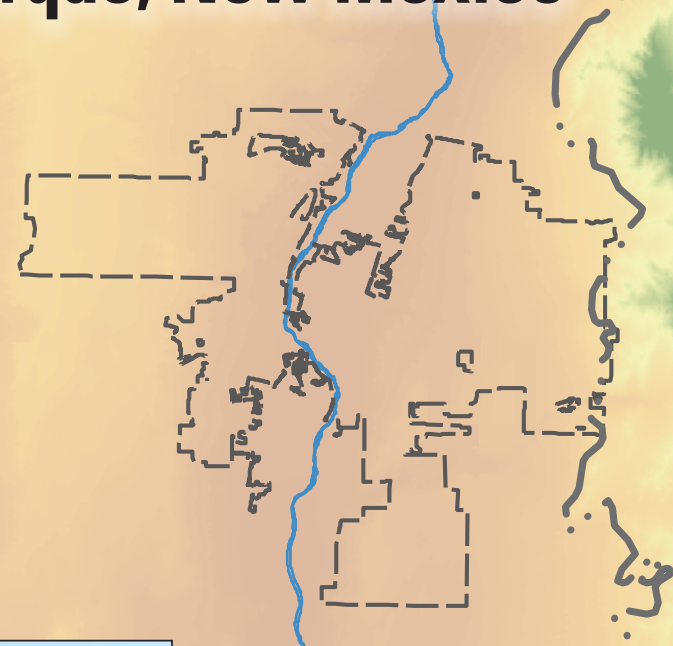

U.S. Department of the Interior U.S. Geological Survey

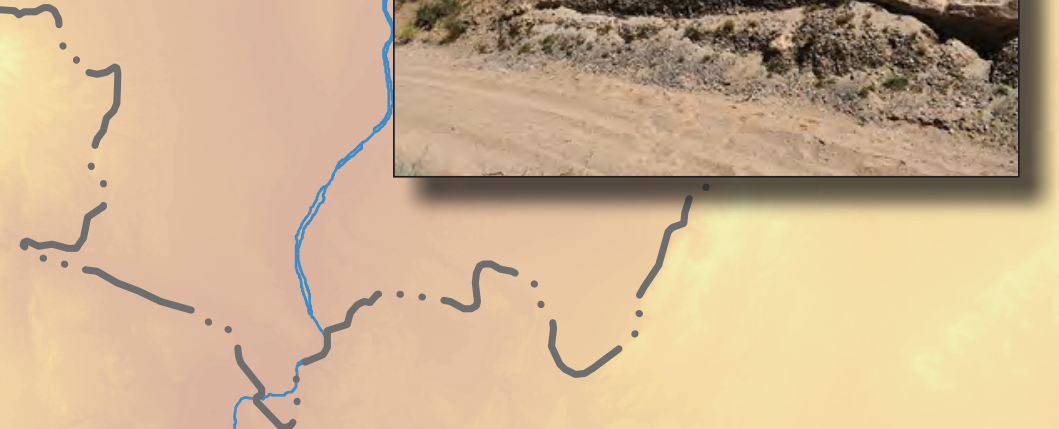




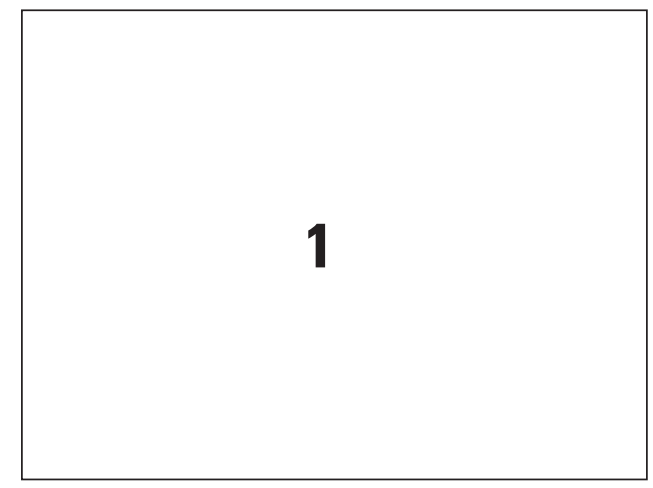

2

3

Cover photos. 1. Rebecca Travis and Alanna Jornigan (USGS) processing water-quality samples. Photograph by Kate Wilkins, USGS. 2. Construction of the Southern sentinel wells. Photograph by Fred Gebhardt, USGS. 3. Outcrop of the Santa Fe Group. Photograph by Amy Galanter, USGS. 


\section{Utilizing Multiple Hydrogeologic and Anthropogenic Indicators to Understand Zones of Groundwater Contribution to Water-Supply Wells Near Kirtland Air Force Base Bulk Fuels Facility in Southeast Albuquerque, New Mexico}

By Rebecca E. Travis, Meghan T. Bell, Benjamin S. Linhoff, and Kimberly R. Beisner

Prepared in cooperation with the Air Force Civil Engineer Center

Scientific Investigations Report 2021-5076 


\section{U.S. Geological Survey, Reston, Virginia: 2021}

For more information on the USGS - the Federal source for science about the Earth, its natural and living resources, natural hazards, and the environment—visit https://www.usgs.gov or call 1-888-ASK-USGS.

For an overview of USGS information products, including maps, imagery, and publications, visit https://store.usgs.gov/.

Any use of trade, firm, or product names is for descriptive purposes only and does not imply endorsement by the U.S. Government.

Although this information product, for the most part, is in the public domain, it also may contain copyrighted materials as noted in the text. Permission to reproduce copyrighted items must be secured from the copyright owner.

Suggested citation:

Travis, R.E., Bell, M.T., Linhoff, B.S., and Beisner, K.R., 2021, Utilizing multiple hydrogeologic and anthropogenic indicators to understand zones of groundwater contribution to water-supply wells near Kirtland Air Force Base Bulk Fuels Facility in southeast Albuquerque, New Mexico: U.S. Geological Survey Scientific Investigations Report 2021-5076, 28 p., https://doi.org/10.3133/sir20215076.

Associated data for this publication:

Bell, M.T., Ferguson C., and Brown, J.E., 2018, Description of groundwater monitoring wells installed at and near Kirtland Air Force Base, Albuquerque, New Mexico, 2013-2016 (ver. 1.2, May 2019): U.S. Geological Survey data release, https://doi.org/10.5066/F7NV9HHG.

U.S. Geological Survey, 2019, USGS water data for the Nation: U.S. Geological Survey National Water Information System database, https://doi.org/10.5066/F7P55KJN.

ISSN 2328-0328 (online) 


\section{Acknowledgments}

This study was supported by the Air Force Civil Engineer Center. The authors would like to thank the U.S. Geological Survey (USGS) hydrologic technicians who conducted the water-quality sampling and the USGS New Mexico Water Science Center staff and colleague reviewers Laura Bexfield and Jerry Casile. 



\section{Contents}

Acknowledgments ……...................................................................................................................

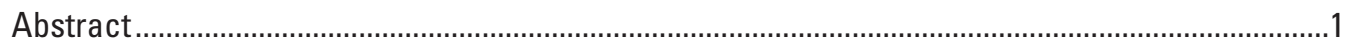

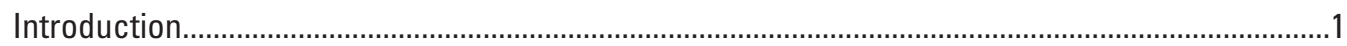

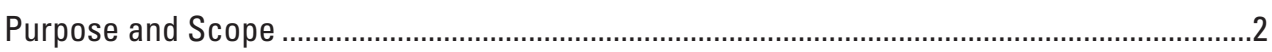

Study Area

Geology and Hydrogeology ....................................................................................... 2

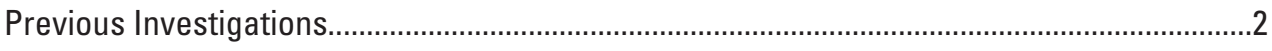

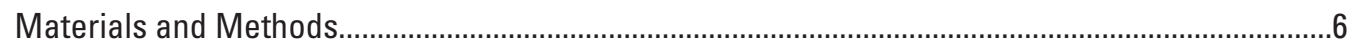

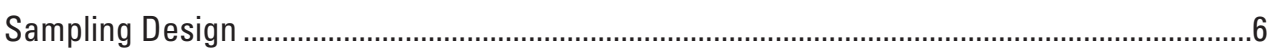

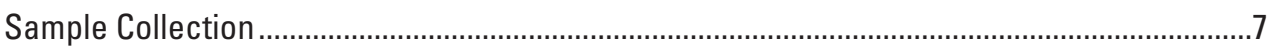

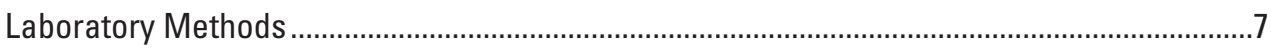

Quality Assurance/Quality Control..............................................................................................

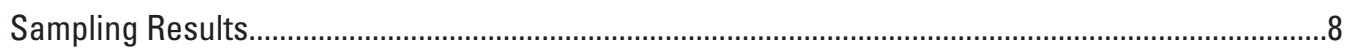

Quality Assessment ..........................................................................................................

General Chemistry and Isotopic Data .............................................................................

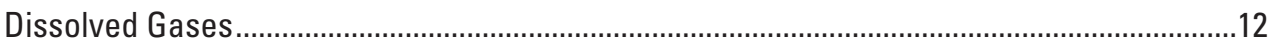

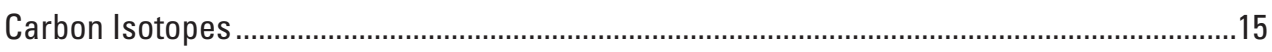

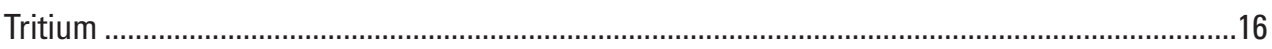

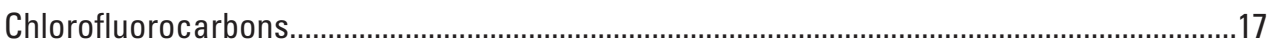

Identification of Primary Zone of Contribution From Groundwater ..............................................18

Groundwater Evolution ...............................................................................................18

Determining Primary Aquifer Zones Contributing to Water-Supply Wells.............................20

Shifting Groundwater Directions and the Comparison of Hydrochemical Zones of

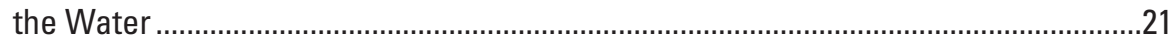

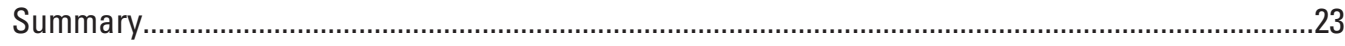

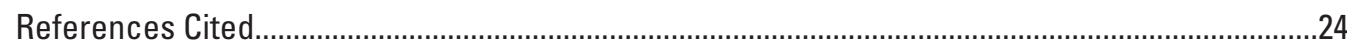

\section{Figures}

1. Map showing study area showing U.S. Geological Survey sentinel well nests, which include the aquifer-test pumping wells, and the nearby water-supply wells in Albuquerque, New Mexico .....

2. Graph showing schematic of well construction for water table, shallow, middle and deep sentinel wells, aquifer-test pumping wells, and water-supply wells ................6

3. Graphs showing general chemical composition plot of water from the sentinel wells, aquifer-test pumping wells, and water-supply wells.

4. Graphs showing selected field properties, major ions, and trace elements plotted against well depth for sampled sentinel wells, aquifer-test pumping wells, and water-supply wells

5. Graph showing results from stable isotope of hydrogen and stable isotope of oxygen analyses...

6. Map showing sentinel well nests and water-supply wells in relation to the Plummer and others (2012) lines of equal stable isotope of hydrogen isotopic composition and geochemical zones. 
7. Graph showing noble gas recharge temperature and elevation

8. Graph showing carbon-14 compared to isotopes of carbon in the sentinel wells, aquifer-test pumping wells, and water-supply wells.

9. Graphs showing stoichiometric plots of groundwater samples. Elemental ratios were all calculated using molarity.

10. Chloride to bromide ratio compared to concentrations of chloride for sentinel wells, aquifer-test pumping wells, and water-supply wells

\section{Tables}

1. List of all sentinel wells, aquifer-test pumping wells, and water-supply wells, including well construction information, and discrete water-quality sampling dates .....4

2. Blank analysis results for major ions and trace elements...............................................

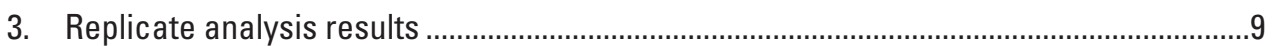

4. Modeled dissolved gas recharge temperatures and elevations.....................................14

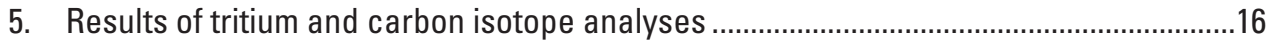

6. Chlorofluorocarbon results and interpretation...........................................................19

7. Summary of anthropogenic inputs, recharge sources, and groundwater age at the wells included in this study.

\section{Conversion Factors}

U.S. customary units to International System of Units

\begin{tabular}{rcc}
\hline Multiply & By & To obtain \\
\hline & Radioactivity & \\
\hline picocurie per liter $(\mathrm{pCi} / \mathrm{L})$ & 0.037 & becquerel per liter $(\mathrm{Bq} / \mathrm{L})$ \\
\hline
\end{tabular}

International System of Units to U.S. customary units

\begin{tabular}{lcl}
\hline & Multiply & \multicolumn{1}{c}{ By obtain } \\
\hline & Length & \\
\hline micrometer $(\mu \mathrm{m})$ & $3.937 \times 10^{-5}$ & inch (in.) \\
meter $(\mathrm{m})$ & 3.281 & foot (ft) \\
\hline \multicolumn{3}{c}{ Area } \\
\hline square kilometer $\left(\mathrm{km}^{2}\right)$ & 247.1 & acre \\
\hline \multicolumn{3}{l}{ Volume } \\
\hline liter $(\mathrm{L})$ & 33.81402 & ounce, fluid (fl. oz) \\
liter $(\mathrm{L})$ & 2.113 & pint (pt) \\
liter $(\mathrm{L})$ & 1.057 & quart (qt) \\
liter $(\mathrm{L})$ & 0.2642 & gallon (gal) \\
cubic centimeter $\left(\mathrm{cm}^{3}\right)$ & 0.06102 & cubic inch (in $\left.{ }^{3}\right)$ \\
\hline
\end{tabular}

Temperature in degrees Celsius $\left({ }^{\circ} \mathrm{C}\right)$ may be converted to degrees Fahrenheit $\left({ }^{\circ} \mathrm{F}\right)$ as follows: ${ }^{\circ} \mathrm{F}=\left(1.8 \times{ }^{\circ} \mathrm{C}\right)+32$. 


\section{Datum}

Vertical coordinate information is referenced to the North American Vertical Datum of 1988 (NAVD 88), except when noted as National Geodetic Vertical Datum of 1929 (NGVD 29).

Horizontal coordinate information is referenced to the North American Datum of 1983 (NAD 83).

Elevation, as used in this report, refers to distance above the vertical datum.

\section{Supplemental Information}

Specific conductance is given in microsiemens per centimeter at 25 degrees Celsius $(\mu \mathrm{S} / \mathrm{cm}$ at $\left.25^{\circ} \mathrm{C}\right)$.

Concentrations of chemical constituents in water are given in either milligrams per liter (mg/L) or micrograms per liter $(\mu \mathrm{g} / \mathrm{L})$.

Activities for radioactive constituents in water are given in picocuries per liter (pCi/L).

Results for measurements of stable isotopes of an element (with symbol E) in water, solids, and dissolved constituents commonly are expressed as the relative difference in the ratio of the number of the less abundant isotope (iE) to the number of the more abundant isotope of a sample with respect to a measurement standard. 


\section{Abbreviations}

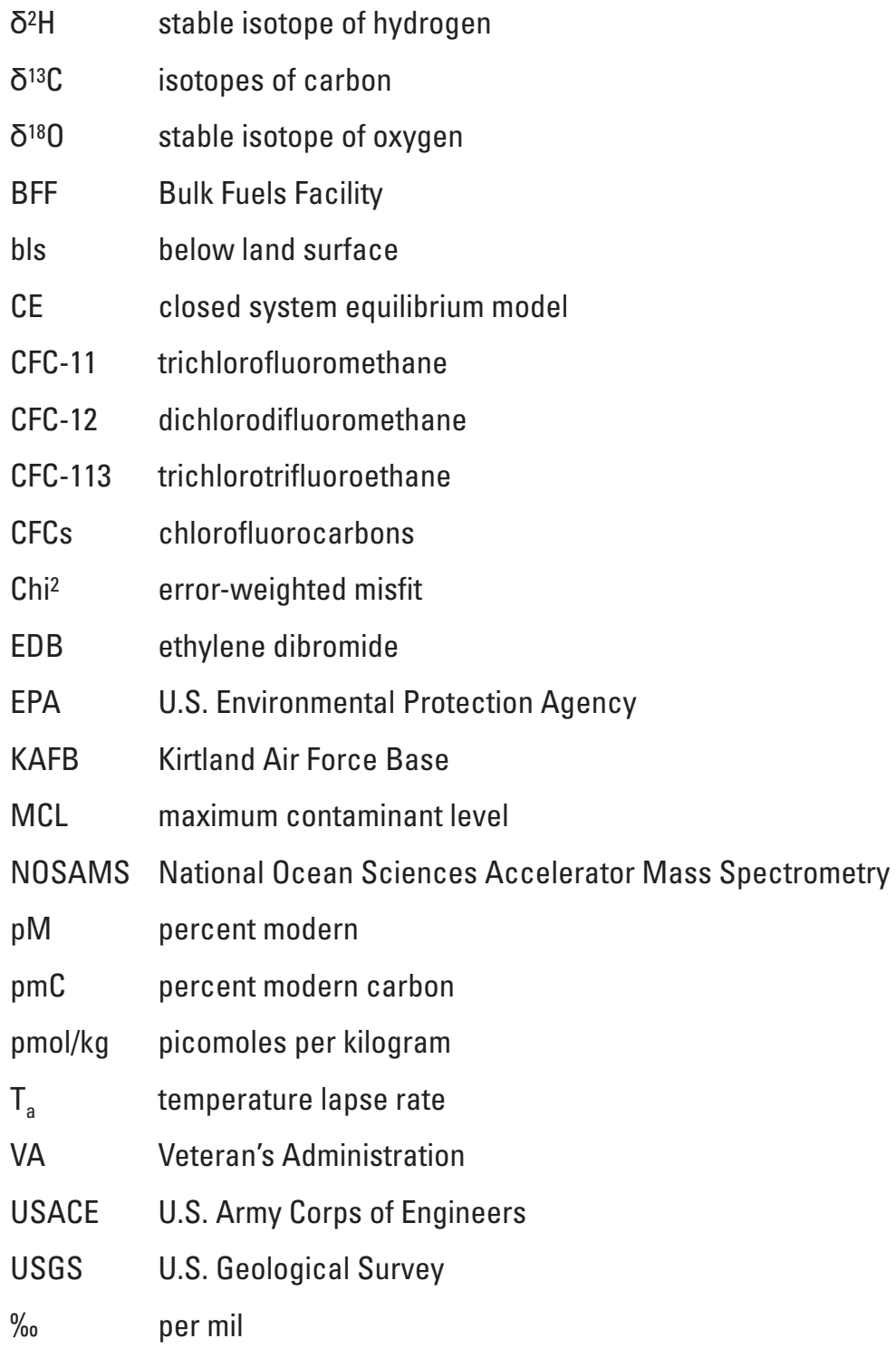




\title{
Utilizing Multiple Hydrogeologic and Anthropogenic Indicators to Understand Zones of Groundwater Contribution to Water-Supply Wells Near Kirtland Air Force Base Bulk Fuels Facility in Southeast Albuquerque, New Mexico
}

\author{
By Rebecca E. Travis, Meghan T. Bell, Benjamin S. Linhoff, and Kimberly R. Beisner
}

\section{Abstract}

In 1999, a jet-fuels release was discovered at the Bulk Fuels Facility on Kirtland Air Force Base, Albuquerque, New Mexico. Contaminants had reached the water table and migrated north-northeast toward water-supply wells. Monitoring wells were installed downgradient from the facility to determine the primary zones of groundwater production for water-supply wells and assess contaminant presence. The monitoring wells are screened within the Santa Fe Group aquifer system, which includes clay units, at depths as great as 445 meters below land surface, and were categorized as water table, shallow, middle, deep, and aquifer-test pumping wells. Water-supply wells are screened across multiple water-bearing units within the aquifer system. All wells were sampled for major ions, trace elements, nutrients, stable isotopes, dissolved gases, tritium, carbon isotopes, and chlorofluorocarbons. The deeper and water-supply wells have evidence of longer groundwater residence times, as much as thousands of years, and water from the shallower wells shows evidence of anthropogenic nutrient inputs. Aquifer recharge is derived from either the mountain front or seepage from the Rio Grande. Dissolved-gas data indicate that the middle, deep, and aquifertest pumping, and water-supply wells have cooler recharge temperatures than the shallower wells. Inferred groundwater age varies by method but indicates that the deeper, aquifertest pumping, and water-supply wells have older water, as much as 15,000 years before present. Results indicate that the water-supply wells draw primarily from the middle and deeper portions of the aquifer system below the clay units and have not been affected by the contaminant plume, although some data indicate a potential for modern water entering some of the deeper and water-supply wells.

\section{Introduction}

In 1999, a jet-fuels release was discovered at the Bulk Fuels Facility (BFF) on Kirtland Air Force Base (KAFB), Albuquerque, New Mexico (fig. 1). Further investigation revealed that jet-fuels related contaminants, in particular ethylene dibromide (EDB), had reached the water table and were migrating north-northeast in the general direction of water-supply wells (U.S. Air Force, 2011). By 2017, the EDB plume extended approximately 1,800 meters (m) (U.S. Army Corps of Engineers [USACE], 2018) northeast of the BFF, and at its deepest, the plume extended $26 \mathrm{~m}$ below the water table in 2015 (USACE, 2017).

Between 2013 and 2016, the U.S. Geological Survey (USGS), in collaboration with the Albuquerque Bernalillo County Water Utility Authority and the Air Force Civil Engineer Center, installed four nests of monitoring wells containing 3 to 7 wells each, screened from 130 to $445 \mathrm{~m}$ below land surface (bls) (fig. 2) and hereafter referred to as "sentinel wells." Following construction and development, these well nests were sampled and analyzed for a suite of analytes, including major ions, trace elements, and stable isotopes. At least 6 months after construction and development, carbon isotopes, chlorofluorocarbons (CFCs), dissolved gases, and tritium were sampled at the well nests. The objective of the sampling was to determine the primary aquifer zone contributing water to water-supply wells and sentinel wells. The major contributing aquifer zone can then be compared to the groundwater affected by jet-fuels related contaminants. A two-pronged strategy that used flow logging and water-quality sampling was utilized to achieve study objectives. The flowlogging study (Travis and Myers, 2019) indicated that most of the water contributing to the wells originated below confining units within the aquifer system. 


\section{Purpose and Scope}

The primary purpose of this report is to identify the primary zone of contribution of groundwater to water-supply wells in the study area using geochemical lines of evidence. Data used in the analysis include water-quality data collected from the aquifer-test pumping and sentinel wells between 2013 and 2017; water-quality data collected from water-supply wells RC-3, RC-4, and RC-5 as part of a previous study (Plummer and others, 2012) in 1996 and 1997; and water quality data collected from RC-3 and RC-5 in 2013 as part of this study (table 1).

\section{Study Area}

The study area is located in the Middle Rio Grande Basin in central New Mexico (fig. 1). The basin encompasses approximately 7,925 square kilometers along the Rio Grande Valley, through which the Rio Grande flows from north to south (Thorn and others, 1993). The basin is bounded on the north, east, and south by mountains and on the west by a plateau. Regional groundwater flow is generally southward, although in the study area, local groundwater flow is northeastward (Powell and McKean, 2014). This localized flow direction is interpreted to be the result of historical groundwater pumping in the region. Recent changes in water resource management have resulted in a decrease in groundwater withdrawals and an associated rapid decrease in groundwater gradient in the study area (Galanter and Curry, 2019).

\section{Geology and Hydrogeology}

The Middle Rio Grande Basin is one of a series of alluvial basins located in the Rio Grande Rift Valley and contains approximately $4,300 \mathrm{~m}$ of alluvial fill in the deepest parts of the basin (Thorn and others, 1993). These sediments are primarily alluvium and colluvium, and the primary aquifer system of the basin is composed of the Oligocene-Pleistocene aged Santa Fe Group and more recent deposits. The formation of interest in this study is the Sierra Ladrones Formation of the Santa Fe Group, deposited during the Pliocene and early Pleistocene, which has been divided into two members, the axial-fluvial member (QTsa) and the piedmont member (QTsp) (Connell, 2006).

QTsa is the lower member of the Sierra Ladrones Formation and is typically associated with axial-fluvial deposits of the ancestral Rio Grande, generally considered to be the most productive water-bearing deposits in the basin. QTsa is a pebbly to cobbly gray to yellowish-brown sand with interbedded mud. Clasts are rounded and are typically volcanic lithic fragments and quartz arenite (Connell, 2006). Locally, the member is interbedded with two distinct layers, identified by Connell and others (1998) as sand and silt-clay sequences, but observed to be primarily clay and silt-clay in the study area (Bell and others, 2018). QTsp is the upper member of the Sierra Ladrones Formation and is a piedmont facies that progrades onto the lower member from the eastern uplands; the depositional environment is generally interpreted as alluvial fan. The QTsp is composed of poorly consolidated red to yellowish-brown conglomerate and sandstone with minor mudstone. Clasts in the conglomerate are typically limestone, sandstone, and granite (Connell, 2006), containing quartz, mica, plagioclase, and potassium feldspars (Plummer and others, 2012). These two layers are present throughout the study area and generally act as confining units, separating the member into three water-bearing units - an unconfined aquifer and two confined or semiconfined aquifers (Myers and Friesz, 2019). The clay and silt-clay units will be referred to in this paper as "A1" and "A2," and the top of each unit is located at approximately 356 and $249 \mathrm{~m}$ bls, respectively (fig. 2; Myers and Friesz, 2019). Note that the tops of A1 and A2 vary by approximately $10 \mathrm{~m}$ in the study area. The subdivision of QTsa below A1 is considered deep, the subdivision between the $\mathrm{A} 1$ and $\mathrm{A} 2$ units is considered intermediate, or middle, and the QTsa that is located above the A2 unit is considered shallow. Throughout this report, wells that are screened in one of these intervals are classified by location relative to the $\mathrm{A} 1$ and A2 units.

\section{Previous Investigations}

Groundwater quality in the Middle Rio Grande Basin has been the focus of several investigations, and the area surrounding the BFF and KAFB has been investigated extensively prior and subsequent to the discovery of the jet-fuels release in 1999.

Bexfield and others (1999) summarized data that had been collected by the City of Albuquerque from 1988 through 1997 from its water-supply wells across the Middle Rio Grande Basin. Bexfield and Anderholm (2002) discussed spatial and temporal variations in those data for the aquifer system and determined that evapotranspiration, land-use practices, water sources, and groundwater flow paths likely explain geochemical variations observed between varying aquifer depths in the basin.

Plummer and others (2004 and 2012) used extensive chemical and isotopic data, collected in the mid to late 1990s, to refine the conceptual model of groundwater flow in the Middle Rio Grande Basin. These studies identified distributions of chemical and isotopic constituents and tied them to potential sources of recharge. Based on those distributions, several different hydrochemical zones were identified across the basin. This study provided a robust source of background data for the study area.

Bexfield and others (2012) analyzed groundwater flow and chemistry data from 22 monitoring wells and 3 watersupply wells to better understand transport processes in the Albuquerque area. The water-supply wells studied had screened intervals that ranged from approximately 97 to $365 \mathrm{~m}$ bls. Results of the analysis indicate that although the 


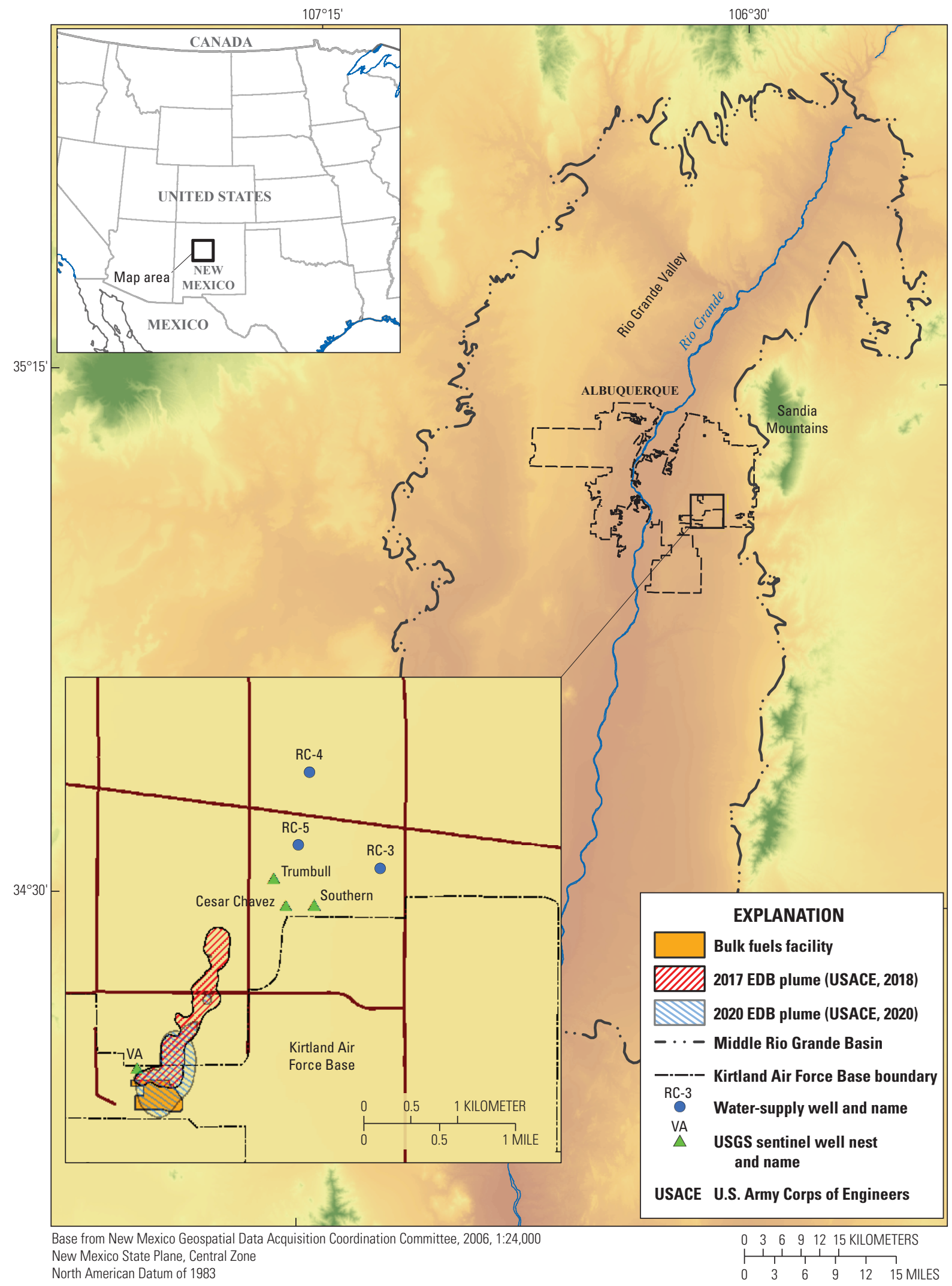

Figure 1. Study area showing U.S. Geological Survey (USGS) sentinel well nests, which include the aquifer-test pumping wells, and the nearby water-supply wells in Albuquerque, New Mexico. Figure inset also shows the location of the bulk fuels facility and the ethylene dibromide (EDB) plume (USACE, 2018). 


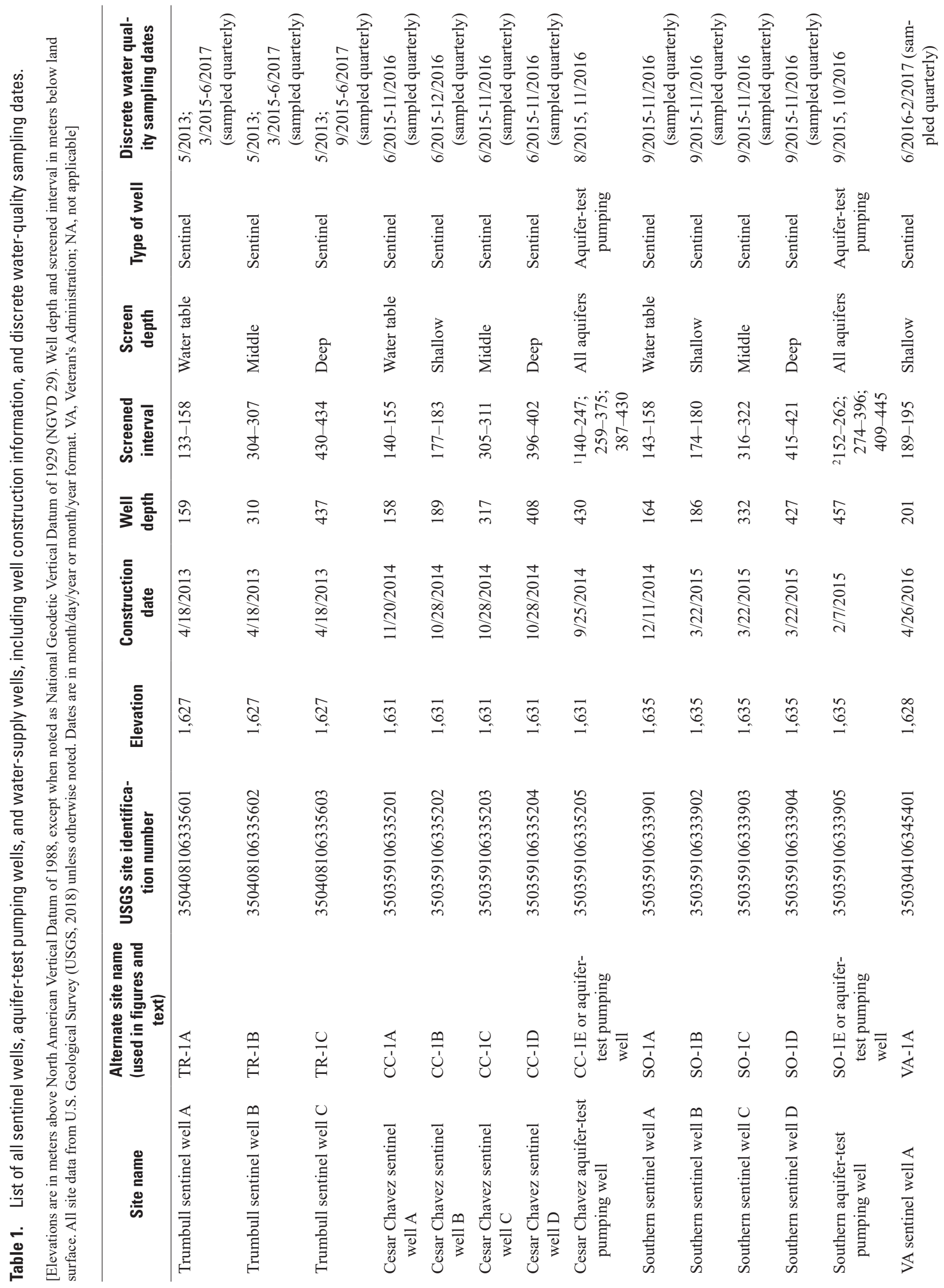




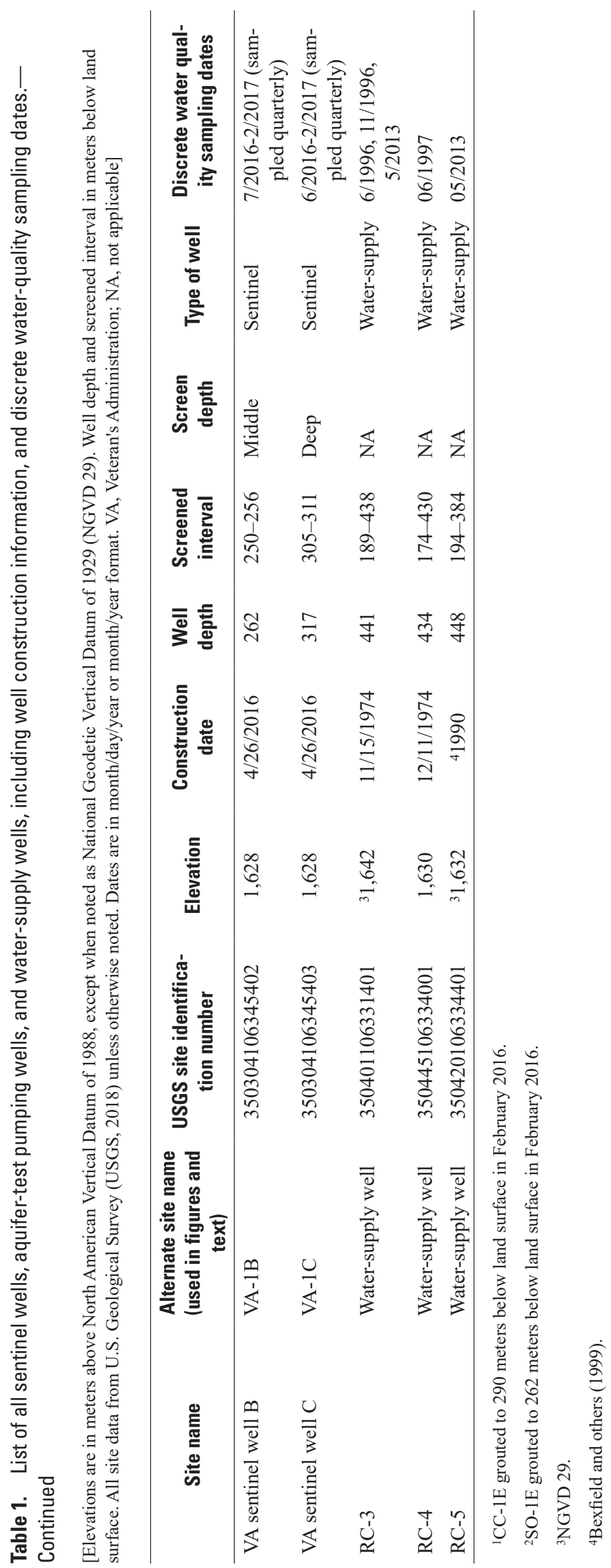




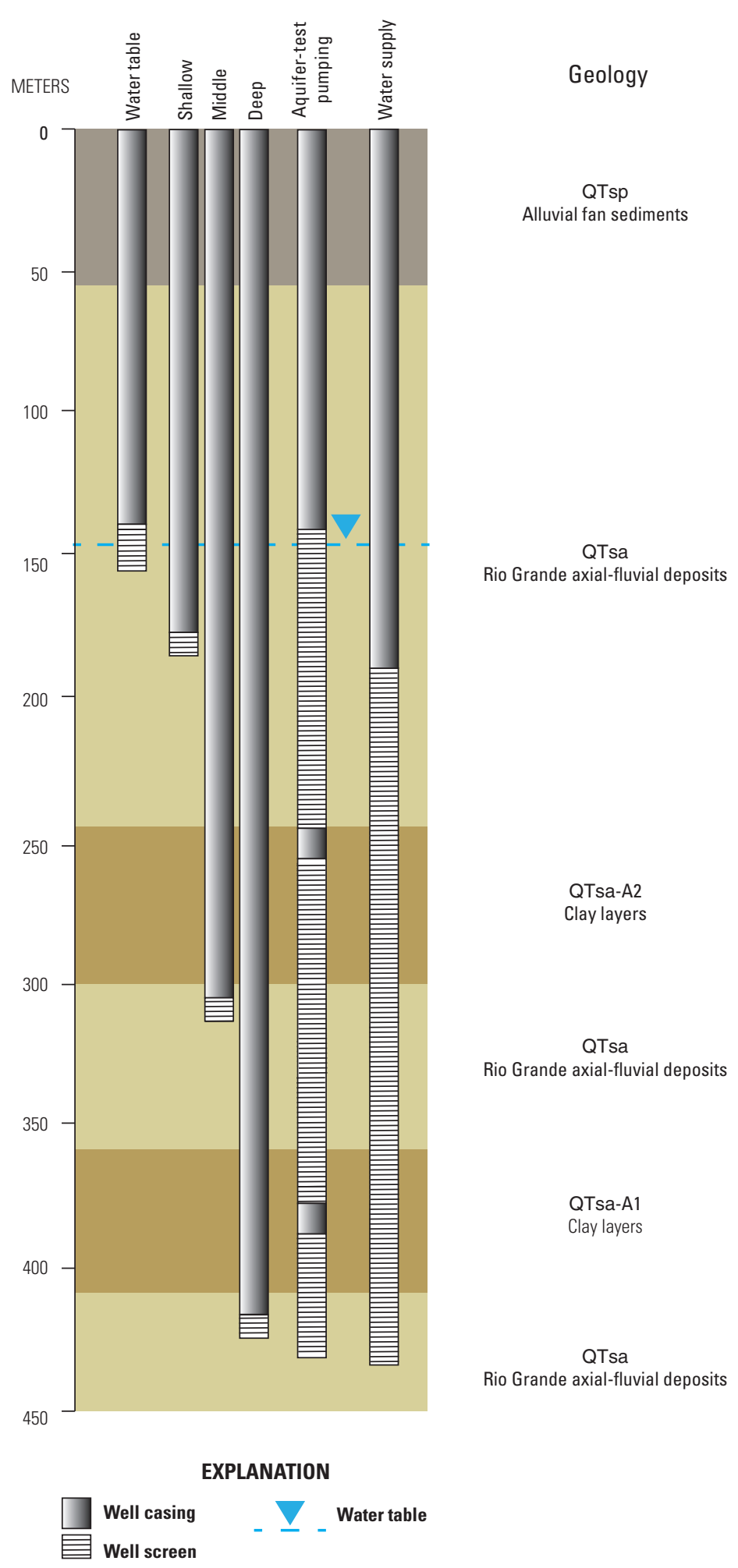

Figure 2. Schematic of well construction for water table, shallow, middle and deep sentinel wells, aquifer-test pumping wells, and water-supply wells. Construction schematic shows locations of the screened intervals and their relation to the local stratigraphy (adapted from Travis and Myers, 2019). water-supply wells were dominated by older water, a small fraction of younger, potentially human-influenced water was reaching depths similar to the screened intervals of water-supply wells in the Middle Rio Grande Basin.

The results of a borehole flow-logging study (Travis and Myers, 2019), coinciding with data collection for this study, indicated that the aquifer-test pumping wells, constructed similarly to water-supply wells, are producing most of their water, under both nonpumping and pumping (at approximately 380 liters per minute) conditions, beneath a confining unit, denoted A2 and the top of which is located between 239 and $250 \mathrm{~m}$ bls in the study area (fig. 2). In 2015, evidence of the EDB plume was limited to the aquifer above the confining unit (USACE, 2017). Construction details of the USGS sentinel wells are found in Bell and others (2018).

\section{Materials and Methods}

This section of the report describes the sampling design and collection of samples. Laboratory methods used to analyze the samples also are described. Lastly, quality assurance and quality control for the samples are described.

\section{Sampling Design}

Data for this study were collected from multiple types of wells, classified in this report as water-supply wells, aquifer-test pumping wells, and sentinel wells (table 1). These wells are categorized by depth of the screened interval for the purpose of data analysis (table 1, fig. 2). The wells with screens that cross the A1 and A2 units and, therefore, produce water from the upper, middle, and lower QTsa, are the three water-supply wells (RC-3, RC-4, and RC-5) and the two aquifer-test pumping wells (Cesar Chavez aquifer-test pumping well and Southern aquifer-test pumping well). Three wells are screened at the water table in the shallow QTsa unit (Trumbull sentinel well A, Cesar Chavez sentinel well A, and Southern sentinel well A). Three wells screened below the water table, in the upper QTsa unit but above the A2 unit (Cesar Chavez sentinel well B, Southern sentinel well B, and Veteran's Administration [VA] sentinel well A), are categorized as shallow. Four wells screened between the A2 and A1 units, in the middle QTsa unit (Trumbull sentinel well B, Cesar Chavez sentinel well C, Southern sentinel well C, and VA sentinel well B), are categorized as being middle wells. Four wells (Trumbull sentinel well C, Cesar Chavez sentinel well D, Southern sentinel well D, and VA sentinel well C) are categorized as deep wells, as they are screened below the A1 unit in the lower QTsa unit. The aquifer-test pumping wells at 
Cesar Chavez and Southern were initially screened to mimic nearby water-supply wells but were grouted to 290 and $262 \mathrm{~m}$ bls, respectively, in February 2016. Samples were collected at the aquifer-test pumping wells both before and after grouting was performed.

Samples were collected for a variety of analytes to fully characterize the groundwater produced from each screened interval. Major ions, trace elements, and nutrients were sampled from each well to provide information on the general chemical composition, as well as to identify the position of each well along a flow path. Stable isotopes and dissolved gases were sampled to provide information on recharge source and temperature. Carbon isotopes, tritium, and CFCs were sampled to provide data that could be used to estimate the age of water within the different intervals.

This analysis incorporates data from 109 water-quality samples. The sentinel wells (14 wells, 98 quarterly samples total) and aquifer-test pumping wells ( 2 wells, 4 annual samples total) were sampled between 2013 and 2017 (table 1). The water-supply wells were sampled by the USGS in 1996 and 1997 (2 wells, 3 samples; Plummer and others, 2012), and in 2013 for this study ( 2 wells, 3 samples).

\section{Sample Collection}

Water-quality samples were collected for this study during 2013-17 in accordance with procedures described in the USGS National Field Manual (USGS, variously dated). A submersible pump was used to purge three well casing volumes and to sample each sentinel well. The Trumbull, Cesar Chavez, and Southern sentinel wells (A, B, C, and D wells) had dedicated pumps. The VA sentinel wells were sampled with a portable pump until February 2017 and were then sampled with dedicated pumps in February 2017. The USGS Research Drilling Program installed high-capacity submersible pumps in the aquifer-test pumping wells because of the large amount of water pumped from those wells. Cleaning and decontamination procedures were in accordance with USGS National Field Manual guidance (USGS, variously dated) for the portable pump, excluding the dedicated and highcapacity submersible pumps. Dedicated pumps were cleaned in accordance with USGS National Field Manual guidance (USGS, variously dated) before placement, but they were not cleaned prior to the second sampling event, as they were in place within the well. The high-capacity pump exterior was cleaned with a nonphosphate laboratory soap and rinsed with water, and the interior of the pump was flushed with thousands of gallons of groundwater during an aquifer test prior to sampling.

Field properties were measured during well purging, including dissolved oxygen, turbidity, specific conductance, $\mathrm{pH}$, and water temperature (USGS, variously dated). Water samples were filtered ( 0.45 micron) for major cations, trace elements, alkalinity, and carbon-14 $\left({ }^{14} \mathrm{C}\right)$. The major cations and trace elements samples were preserved to $\mathrm{pH}$ less than $(<) 2$ by adding ultrapure nitric acid. Unfiltered samples were collected for stable isotopes, tritium, CFCs, and dissolved and noble gases. Alkalinity was titrated in the field by using the incremental equivalence method (USGS, variously dated). Water-quality data are available from the USGS National Water Information System database (USGS, 2018), with the exception of the 1996 and 1997 data from RC-3 and RC-4, which can be found in Plummer and others (2012). The data can be retrieved from the database by using the USGS site identification numbers in table 1.

\section{Laboratory Methods}

Water samples were analyzed for major ions, trace elements, and nutrients by the USGS National Water Quality Laboratory in Denver, Colorado. Inductively coupled plasmamass spectrometry was used for the following elements: aluminum, antimony, arsenic, barium, beryllium, boron, cadmium, chromium, cobalt, copper, lead, lithium, manganese, molybdenum, nickel, selenium, silver, strontium, thallium, uranium, vanadium, and zinc (Garbarino, 1999; Garbarino and others, 2006).

Ion-exchange chromatography was used to analyze for chloride, fluoride and sulfate (Fishman, 1993), and calcium, iron, magnesium, manganese, sodium, potassium, and silicon dioxide were analyzed by inductively coupled plasma optical emission spectrophotometry (Fishman and Friedman, 1989). Nitrate plus nitrite (hereafter referred to as "nitrate") was analyzed by colorimetry (Patton and Kryskalla, 2011). Major ions and nutrients are reported in milligrams per liter, and trace elements are in micrograms per liter.

The dissolved gases argon (Ar), carbon dioxide, methane, nitrogen $\left(\mathrm{N}_{2}\right)$, and oxygen were analyzed by the USGS Reston Groundwater Dating Laboratory in Reston, Virginia, by using a gas chromatograph (USGS, 2019). The ratio of $\mathrm{N}_{2}$ to $\mathrm{Ar}$ is hereafter referred to as " $\mathrm{N}_{2} /$ Ar." Dissolved gases are reported in milligrams per liter. Dissolved noble gases (argon, helium $[\mathrm{He}]$, krypton [Kr], neon, and xenon [Xe]) were analyzed by the USGS Noble Gas Laboratory in Denver, Colo. (Hunt, 2015). Noble gases are reported in cubic centimeters at standard temperature and pressure per gram of water.

Stable isotope ratios $\left(\delta^{18} \mathrm{O}\right.$ and $\left.\delta^{2} \mathrm{H}\right)$ were analyzed at the USGS Reston Stable Isotope Laboratory. The isotopes are analyzed by dual-inlet isotope-ratio mass spectrometry (Révész and Coplen, 2008a, b). Stable isotope ratios are reported in per mil relative to Vienna Standard Mean Ocean Water.

Tritium was analyzed at the University of Miami in Miami, Florida, by using low-level gas proportional counters (Thatcher and others, 1977), with the exception of the sample from TR-1A, which was analyzed by Lamont Doherty Earth Observatory at Columbia University in Palisades, New York. Lamont Doherty analyzes tritium by using the helium-3 ingrowth method (Ludin and others, 1997). Tritium is reported in picocuries per liter. 
${ }^{14} \mathrm{C}$ concentrations and ratios of the stable isotopes of carbon-13 to carbon- $12\left(\delta^{13} \mathrm{C}\right)$, reported relative to the Vienna Pee Dee Belemnite standard of dissolved inorganic carbon, were analyzed by the National Ocean Sciences Accelerator Mass Spectrometry (NOSAMS) at Woods Hole Oceanographic Institution in Woods Hole, Massachusetts. ${ }^{14} \mathrm{C}$ values reported by the NOSAMS as percent modern $(\mathrm{pM})$ were denormalized by using equation 5 of Plummer and others (2012) to percent modern carbon (pmC).

CFCs were analyzed by the USGS Reston Groundwater Dating Laboratory in Reston, Va. Concentrations of trichlorofluoromethane (CFC-11), dichlorodifluoromethane (CFC-12), and trichlorotrifluoroethane (CFC-113) are detected by using purge and trap gas chromatography with electron-capture detection (Busenberg and Plummer, 1992). CFC samples were collected in triplicate, and $\mathrm{CFC}$ results are reported in picomoles per kilogram.

\section{Quality Assurance/Quality Control}

Quality-assurance samples included 32 blanks (field, equipment, source sol ution) and 6 replicate pairs. Field blanks (12 trace element blanks and 7 major ion blanks) were collected between 2016 and 2017. Twelve equipment blanks (trace element blanks and major ion blanks) were collected between 2015 and 2017. Source solution blanks (eight trace element blanks and six major ion blanks) were collected between 2015 and 2017. Results from quality-assurance samples are presented in the "Quality Assessment" section.

When possible, field and equipment blanks were collected by using the entire length of tubing installed in the well, as well as the pump head. However, dedicated pumps were installed in the sentinel wells, so it was not possible to collect field blanks on the in-well tubing and pump heads at the Trumbull, Southern, and Cesar Chavez well nests for most of the study duration. These field blanks were collected by using only the aboveground sample line and a centrifugal pump and not the in-well tubing and pump heads in place within the wells. The Trumbull well pumps were removed prior to the June 2017 sampling event, and at this point, the entire in-well tubing and pump heads were used for field blank collection at the Trumbull wells. There were no permanently installed pumps at the VA well nest, so field and equipment blanks were conducted by using a portable pump, including in-well tubing and pump head.

\section{Sampling Results}

This section of the report first describes the quality assessment using quality assurance samples collected for this study. Then, sampling results for general chemistry, isotopic data, dissolved gases, carbon isotopes, tritium, and CFCs are described.

\section{Quality Assessment}

The number of field blanks with major ion or trace element detections above the detection limit is reported by analyte in table 2 . If an analyte discussed in this report is not included in table 2, it was not detected in blank samples. A concentration representing the potential threshold of influence on concentrations in environmental samples was established at 10 times the greatest blank concentration. All environmental sample concentrations were greater than the threshold of influence for all analytes except boron in equipment blanks, fluoride in equipment blanks, and manganese in equipment and field blanks. The only threshold that would apply to the report dataset would be for manganese, because it was found in the field blanks within a concentration range similar to that of the environmental samples, and an assumption is made that the field blanks are more representative of potential contamination bias than equipment blanks. However, a detailed analysis of manganese concentrations was not conducted in this study, and no threshold was applied.

Replicates were analyzed by evaluating the relative percent difference of six replicate pairs based on methods in Mueller and others (2015; eq. 1, table 3).

$$
\begin{aligned}
& \text { Relative Percent Difference }= \\
& 100 \times \frac{(\text { larger result }- \text { smaller result })}{(\text { larger result }+ \text { smaller result }) / 2}
\end{aligned}
$$

For environmental sampling events with few replicates, Mueller and others (2015) suggest a criterion of 20-percent relative percent difference for replicate pairs to be considered acceptable.

\section{General Chemistry and Isotopic Data}

Samples collected from near the water table; from the shallow, middle, and deep aquifer; and across multiple intervals have several geochemical distinctions. On the Piper plot (fig. 3) (Piper, 1944), the distribution of the major ions is somewhat distinct between samples from the shallow and water table wells compared to those from the middle, deep, aquifer-pumping test, and water-supply wells.

Samples from the water table, middle, deep, aquifer-test pumping, and water-supply wells are calcium-type water, and those from the shallow wells at VA and Southern (VA-1A and SO-1B) are sodium or potassium type. The shallow well samples from VA and Southern are also distinct, with a higher bicarbonate water type than samples from the water table, middle, deep, aquifer-test pumping, and water-supply wells, which have no dominant water type or a lower bicarbonate water type. To delve into these distinctions more, the cation and anion distributions were reviewed.

The water table, middle, deep, aquifer-test pumping, and water-supply well samples had similar cation distributions, containing less than 20 percent magnesium, 30-70 percent calcium, 
Table 2. Blank analysis results for major ions and trace elements.

$[<$, less than; $\mu \mathrm{g} / \mathrm{L}$, micrograms per liter; $\mathrm{mg} / \mathrm{L}$, milligrams per liter $]$

\begin{tabular}{|c|c|c|c|c|c|c|}
\hline Analyte & $\begin{array}{c}\text { Number of } \\
\text { blanks }\end{array}$ & $\begin{array}{l}\text { Number of blanks } \\
\text { with a value greater } \\
\text { than the laboratory } \\
\text { detection level }\end{array}$ & $\begin{array}{l}\text { Concentration } \\
\text { range of blank } \\
\text { detections }\end{array}$ & $\begin{array}{c}\text { Concentration of } \\
\text { threshold of influ- } \\
\text { ence }\end{array}$ & Units & $\begin{array}{l}\text { Percentage of environ- } \\
\text { mental samples below } \\
\text { threshold }\end{array}$ \\
\hline \multicolumn{7}{|c|}{ Equipment blanks } \\
\hline Boron & 12 & 1 & $<5-6$ & 60.0 & $\mu \mathrm{g} / \mathrm{L}$ & 30 \\
\hline Calcium & 11 & 7 & $<0.022-0.048$ & 0.48 & $\mathrm{mg} / \mathrm{L}$ & 0 \\
\hline Fluoride & 11 & 4 & $<0.01-0.16$ & 1.60 & $\mathrm{mg} / \mathrm{L}$ & 100 \\
\hline Manganese & 12 & 7 & $<0.4-2.88$ & 28.8 & $\mathrm{mg} / \mathrm{L}$ & 73 \\
\hline Silica & 11 & 6 & $<0.018-0.08$ & 0.80 & $\mathrm{mg} / \mathrm{L}$ & 0 \\
\hline Uranium & 12 & 2 & $<0.01-0.041$ & 0.41 & $\mu \mathrm{g} / \mathrm{L}$ & 0 \\
\hline \multicolumn{7}{|c|}{ Field blanks } \\
\hline Calcium & 7 & 6 & $<0.022-0.057$ & 0.57 & $\mathrm{mg} / \mathrm{L}$ & 0 \\
\hline Chloride & 6 & 2 & $<0.02-0.05$ & 0.50 & $\mathrm{mg} / \mathrm{L}$ & 0 \\
\hline Manganese & 12 & 4 & $<0.4-3.17$ & 31.7 & $\mathrm{mg} / \mathrm{L}$ & 72 \\
\hline Potassium & 7 & 1 & $<0.03-0.090$ & 0.90 & $\mathrm{mg} / \mathrm{L}$ & 0 \\
\hline Silica & 7 & 3 & $<0.018-0.044$ & 0.40 & $\mathrm{mg} / \mathrm{L}$ & 0 \\
\hline Sodium & 7 & 2 & $<0.10-0.20$ & 2.00 & $\mathrm{mg} / \mathrm{L}$ & 0 \\
\hline Sulfate & 6 & 2 & $<0.02-0.030$ & 0.30 & $\mathrm{mg} / \mathrm{L}$ & 0 \\
\hline
\end{tabular}

Table 3. Replicate analysis results.

\begin{tabular}{lcc}
\hline \multicolumn{1}{c}{ Analyte } & Number of pairs & $\begin{array}{c}\text { Mean relative percent differ- } \\
\text { ence for number of pairs }\end{array}$ \\
\hline Alkalinity & 5 & 3.21 \\
Arsenic & 6 & 2.84 \\
Bicarbonate & 4 & 2.67 \\
Boron & 6 & 1.47 \\
Bromide & 6 & 1.61 \\
Calcium & 6 & 1.85 \\
Chloride & 6 & 0.29 \\
Fluoride & 6 & 1.30 \\
Magnesium & 6 & 1.32 \\
Manganese $^{\text {NO }}+\mathrm{NO}_{3}$ & 6 & 3.54 \\
Potassium & 6 & 1.66 \\
Silica & 6 & 1.18 \\
Sodium & 6 & 1.02 \\
Sulfate & 6 & 2.44 \\
Uranium $^{2}$ & 6 & 0.27 \\
\hline
\end{tabular}

and $20-65$ percent sodium and potassium. The cation distribution in samples from the shallow wells at VA and Southern (VA-1A and SO-1B) was distinct from that of the other wells, containing higher percentages of sodium and potassium (45-65 percent) and lower percentages of calcium (30-50 percent), whereas most samples from other wells contain lower percentages of sodium and potassium and higher percentages of calcium. Anions in samples from the middle, deep, aquifertest pumping, and water-supply wells ranged from 20 to 50 percent chloride and fluoride, 40 to 70 percent bicarbonate and carbonate, and 15 to 20 percent sulfate. Compared to samples from the deeper wells, those from the water table wells had higher percentages of sulfate, 20-30 percent, and a generally lower range of percentages for bicarbonate and carbonate, ranging from 30 to 60 percent. The shallow well samples at VA and Southern (VA-1A and SO-1B) are again distinct, with higher percentages of bicarbonate and carbonate (70-80 percent), lower percentages of chloride and fluoride $(<20$ percent), and slightly lower percentages of sulfate (10-15 percent), whereas the shallow well samples at Cesar Chavez had higher percentages of sulfate and an anion composition similar to that of the water table well samples.

Bexfield and others (2012) and Plummer and others (2012) showed that there were some variations in the chemistry of groundwater with depth in the Santa Fe Group, but, for this study, sample representation was limited by the small number of nested monitoring wells. The observed chemistry 


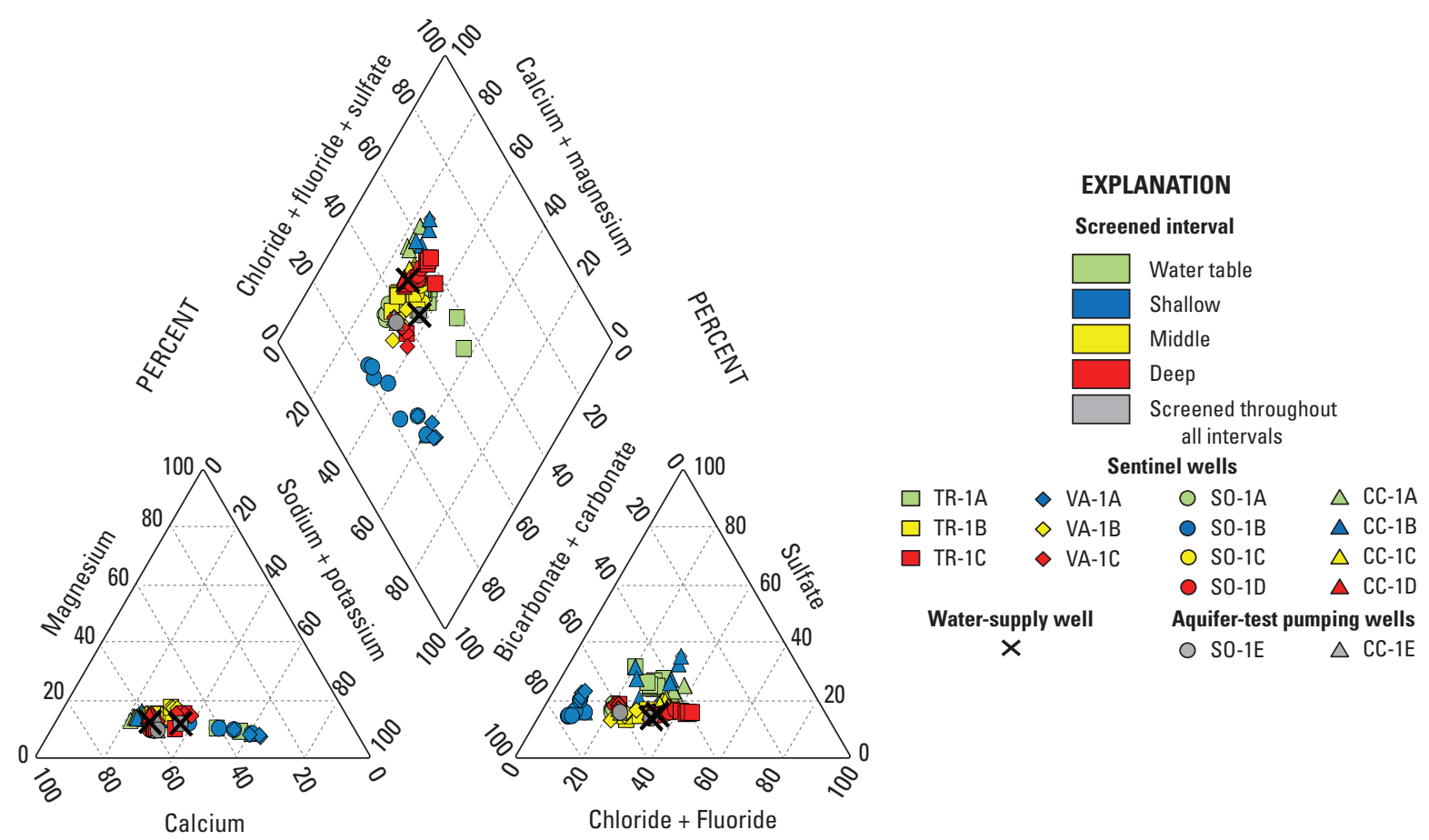

PERCENT

Figure 3. General chemical composition plot of water from the sentinel wells, aquifer-test pumping wells, and water-supply wells.

showed little variation because of the water's contact with primarily the same material throughout the different screened intervals. Plummer and others (2012) found that there was more areal variation than vertical variation; however, the most consistent differences observed vertically and varying with depth were increases in sodium, arsenic, and boron and decreases in calcium. Bexfield and others (2012) found that fluoride, silica, and potassium increased with depth because of the mineral weathering of the origin material in the Santa Fe Group. Some of these distinctions were noted in the sentinel, aquifer-test pumping, and water-supply wells (fig. 4). The field properties also showed some distinction with depth (fig. 4). Water from all wells generally had a pH of greater than 7 standard units. Specific conductance ranged from approximately 300 to 700 microsiemens per centimeter at 25 degrees Celsius $\left(\mu \mathrm{S} / \mathrm{cm}\right.$ at $\left.25^{\circ} \mathrm{C}\right)$ in the water table and shallow wells, 300 to $550 \mu \mathrm{S} / \mathrm{cm}$ in the middle wells, and approximately 450 to $550 \mu \mathrm{S} / \mathrm{cm}$ in the deep wells; aquifertest pumping and water-supply wells were within the range for middle wells. Dissolved oxygen concentration ranged from 0 to 13 milligrams per liter $(\mathrm{mg} / \mathrm{L})$ in the water table and shallow wells and did not exceed $4 \mathrm{mg} / \mathrm{L}$ in the middle and deep wells (fig. 4). Arsenic, potassium, and silica concentrations all increased with depth in the sentinel wells and aquifer-test pumping wells. Arsenic concentrations exceeded the U.S. Environmental Protection Agency (EPA) maximum contaminant level (MCL) of 10 micrograms per liter (EPA, 2019) in all of the deep and aquifer-test pumping wells. The increases in arsenic, potassium, and silica concentrations with depth may indicate longer residence times within the source material (Bexfield and others, 2012). Fluoride concentration did not increase with depth. Sodium concentration did not appear to increase with depth, and the highest concentrations were in the shallow and water table wells. Calcium had a broad concentration range in the shallow and water table wells, as well as the highest concentrations (fig. 4). The middle, deep, and aquifer-test pumping wells had smaller ranges of values in the mid-range concentrations. Concentrations of other elements also varied among the screened intervals (fig. 4). Nitrate concentrations were greater in the shallow and water table wells than in the other wells, but none of the concentrations exceeded the EPA MCL level of $10 \mathrm{mg} / \mathrm{L}$ (EPA, 2019). Uranium concentrations were highest in the deep wells, specifically CC-1D and CC-1E.

Stable isotopes were sampled from all wells. The deep well samples had $\delta^{2} \mathrm{H}$ values ranging from -97.4 to -94.2 per mil (\%o) and $\delta^{18} \mathrm{O}$ values ranging from -13.20 to $-12.90 \%$, whereas samples from the middle aquifers ranged from -96.6 to $-91.4 \% \delta^{2} \mathrm{H}$ and from -13.20 to $-12.50 \%{ }^{18} \mathrm{O}$ (fig. 5). Samples collected from the shallow and water table wells were more variable, from -99 to $-79.6 \%{ }^{2} \mathrm{H}$ and from -13.38 to $-11.25 \% \delta^{18} \mathrm{O}$. The shallow and water table well samples had a bimodal distribution, with most samples being either relatively light (all sentinel wells except for SO-1A and SO-1B) or relatively heavy (SO-1A and SO-1B) (fig. 5). Unlike samples collected from the deep aquifer wells, 

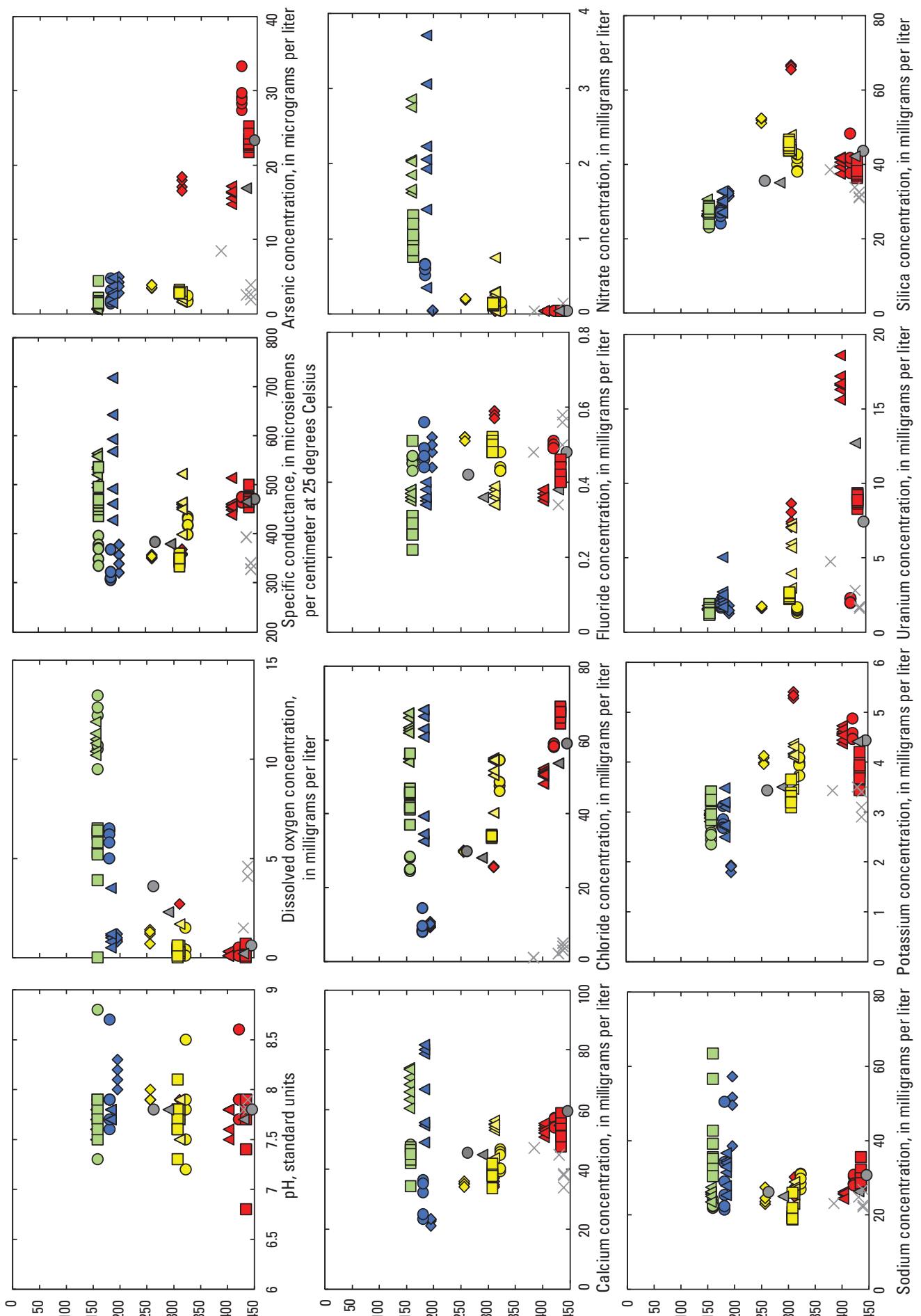

\section{迹}

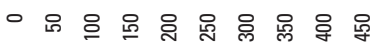

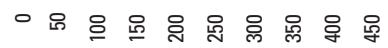

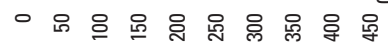

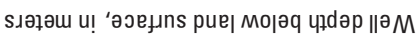

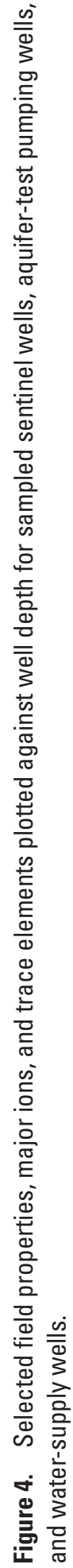


samples from the aquifer-test pumping wells and water-supply wells had a wide range of $\delta^{2} \mathrm{H}$ and $\delta^{18} \mathrm{O}$ values ( -97.3 to $-85.9 \%$ o $\delta^{2} \mathrm{H}$ and -13.20 to $-11.70 \%$ o $\delta^{18} \mathrm{O}$ ) and did not display a bimodal distribution. Analytical results of post-grouting samples from the aquifer-test pumping wells indicate that the water was heavier (fig. 5) than water from the initial sampling event.

Plummer and others (2012) concluded that ranges from -80 to $-85 \%$ o $\delta^{2} \mathrm{H}$ in the study area indicated mountain-front recharge, which was seen in samples from springs and arroyos in the Sandia Mountains, and that more depleted values of -90 to $-100 \%$ o $\delta^{2} \mathrm{H}$ indicated recharge originating as seepage from the Rio Grande, which is sourced by snowmelt from Colorado and northern New Mexico. Samples collected in the 1980s and late 1990s analyzed by the same laboratory using the same method indicate that groundwater in water-supply well RC-3 has a stable isotopic composition of $-85.9 \%$ o $\delta^{2} \mathrm{H}$ (Plummer and others, 2012). However, samples collected from RC-3 in 2013 showed a more depleted value of $-90.1 \%$ and may indicate a change in the source of water to this well (fig. 5). $\mathrm{RC}-3$ is the easternmost well in this study and is near a steep isotopic isopleth boundary presented in Plummer and others (2012) (fig. 6). Samples from SO-1A and SO-1B have $\delta^{2} \mathrm{H}$ values ranging from -79.6 to $-82.6 \%$ and may indicate a different recharge source when compared with samples from SO-1C and SO-1D, which range from -91.6 to $-96.9 \%$ (fig. 5).

\section{Dissolved Gases}

The water table, shallow, middle, and deep sentinel wells were sampled for noble gases, but the aquifer-test pumping wells and water-supply wells were not. Noble gas recharge elevation and temperature were calculated by using $\mathrm{Ne}, \mathrm{Ar}$, $\mathrm{Kr}$, and Xe (table 4) with the closed system equilibration

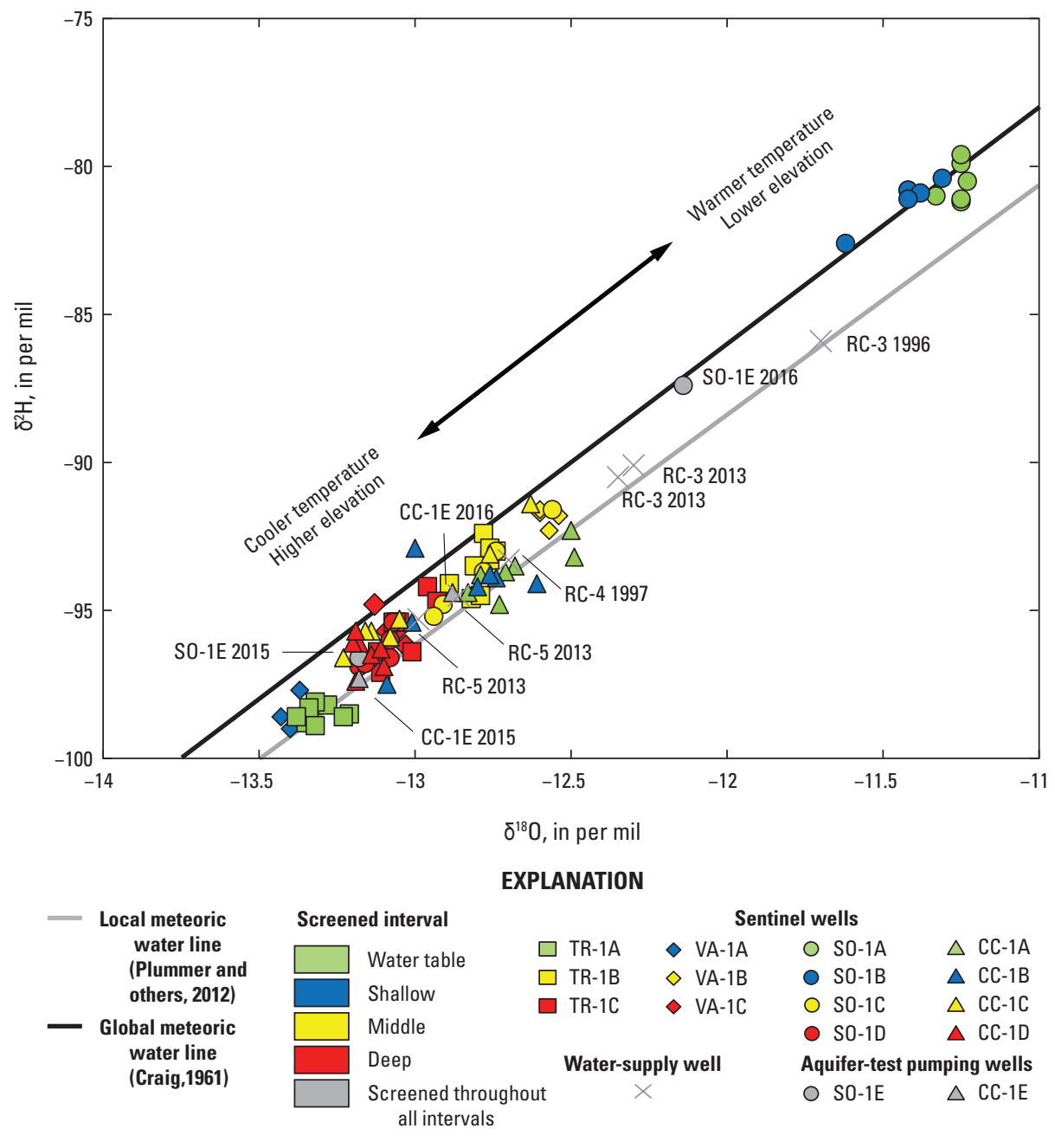

Note: Labeled symbols indicate the year the sample was collected and show temporal changes

Figure 5. Results from stable isotope of hydrogen $\left(\delta^{2} \mathrm{H}\right)$ and stable isotope of oxygen $\left(\delta^{18} \mathrm{O}\right)$ analyses. 


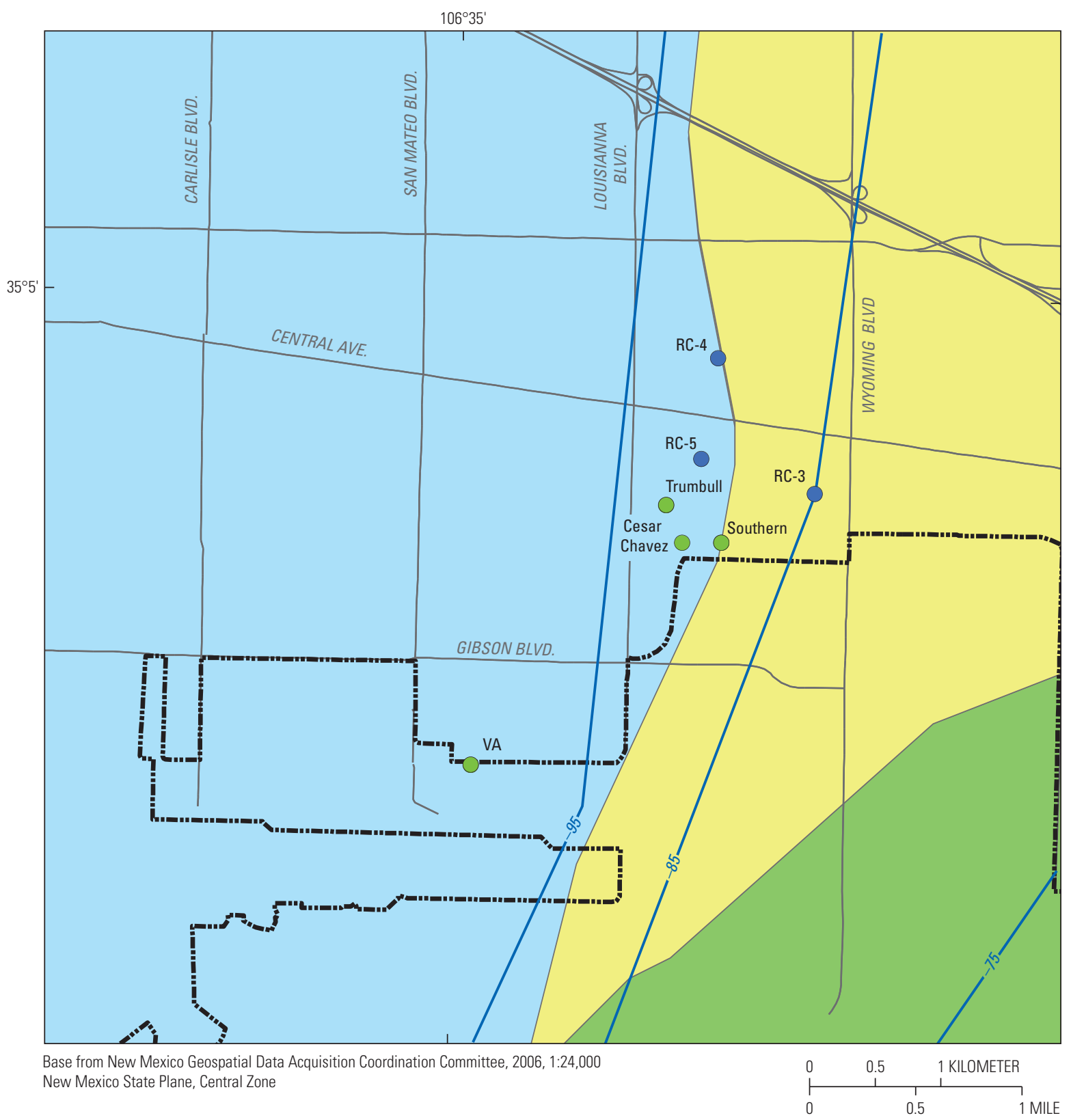

\section{EXPLANATION}

Geochemical zones (Plummer and others, 2012)

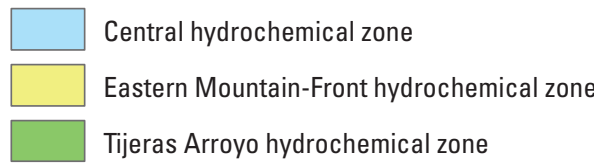

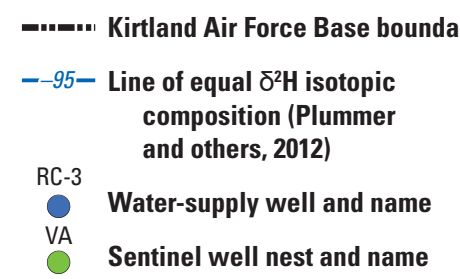

Figure 6. Sentinel well nests and water-supply wells in relation to the Plummer and others (2012) lines of equal stable isotope of hydrogen $\left(\delta^{2} \mathrm{H}\right)$ isotopic composition and geochemical zones. 
model (CE) (Aeschbach-Hertig and others, 2000) and a standard inverse technique (Newton method) to minimize the error-weighted misfit $\left(\mathrm{Chi}^{2}\right)$ between measured and modeled values (Aeschbach-Hertig and others, 1999; Ballentine and Hall, 1999; Manning and Solomon, 2003). A local relation between recharge temperature and elevation can place useful constraints on recharge elevation (Zuber and others, 1995; Aeschbach-Hertig and others, 1999; Manning and Solomon, 2003). A temperature lapse rate $\left(T_{a}\right)$ was calculated for the Albuquerque area based on the modern mean annual air temperature of $13.6^{\circ} \mathrm{C}$ (Plummer and others, 2012) and the mean lapse rate of $-5.5^{\circ} \mathrm{C}$ per kilometer (Meyer, 1992) (fig. 7).

Discharge from springs at 2,012 and 1,951-m elevations in the Sandia Mountains had recharge temperatures of $8-9^{\circ} \mathrm{C}$ (Plummer and others, 2012). Water table temperatures for typical depths below land surface are generally $0-3{ }^{\circ} \mathrm{C}$ above $\mathrm{T}_{\mathrm{a}}$, noted as $\mathrm{T}_{\mathrm{a}+1.5}$ and $\mathrm{T}_{\mathrm{a}+3}$ (Domenico and Schwartz, 1990; Lee and Hahn, 2006; Cey, 2009).

Three samples - CC-1C (environmental and replicate) and TR-1B - have laboratory comments indicating issues that excluded the samples from analysis. Three replicate samples (CC-1A, CC-1B, SO-1A) were analyzed, but only one replicate had a good model fit (CC-1A). Both CC-1A samples (environmental and replicate) have similar calculated recharge temperatures of 5.8 and $4.5^{\circ} \mathrm{C}$. However, these recharge temperatures are unreasonable (too low), resulting from fractionated excess air that is not in equilibrium with atmospheric gases. The fractionated excess air may indicate that there were remnant gases from the well drilling process, which can persist for years after drilling depending on aquifer properties (Busenberg and Plummer, 2010). Samples from SO-1 A and TR-1A were not included in recharge temperature calculations because the model fits for the data were higher than the $T_{a}$ equation (fig. 7). Although the reason for these elevated recharge temperatures was not determined and remains unknown in this study, Plummer and others (2012) suggested that recharge through a thick unsaturated zone could be warmed along a geothermal gradient prior to reaching the water table, which could elevate recharge temperatures. SO-1B results did not fit the solubility model, having a high $\mathrm{Chi}^{2}$ value, and thus were not included. CE model fits that intersect the $\mathrm{T}_{\mathrm{a}+1.5}$ line provide unreasonably high recharge elevations (greater than $[>] 3,000 \mathrm{~m}$ ) for some sites, so the $\mathrm{T}_{\mathrm{a}}$ line was used for the recharge temperatures in this study. Well samples that cross the $\mathrm{T}_{\mathrm{a}}$ line with good $\mathrm{Chi}^{2}$ model fits $(<2.71)$ using the CE model are listed in table 4.

Noble gas recharge temperatures (indicated where CE model values for noble gas recharge cross the $\mathrm{T}_{\mathrm{a}}$ line) ranged from 6.2 to $10.9^{\circ} \mathrm{C}$ (table 4; fig. 7). Generally, the water from deep wells has a lower recharge temperature. The recharge temperatures for modeled middle and deep wells (TR-1C, SO-1C, SO-1D, and VA-1C) ranged from 6.2 to $8.8^{\circ} \mathrm{C}$, whereas recharge temperatures for the shallower wells (VA-1A and VA-1B) were 10.9 and $10.4{ }^{\circ} \mathrm{C}$, respectively. SO-1A and

Table 4. Modeled dissolved gas recharge temperatures and elevations.

[Elevations are in meters above North American Vertical Datum of 1988, except when noted as National Geodetic Vertical Datum of 1929 (NGVD 29). ${ }^{\circ} \mathrm{C}$, degree Celsius; $\mathrm{T}_{\mathrm{a}}$, temperature lapse rate; Ae, initial excess air concentration; ccSTP/g, cubic centimeters at standard temperature and pressure per gram of water; F, fraction of excess air loss; $\mathrm{Chi}^{2}$, Chi-squared statistic; $\mathrm{R} / \mathrm{R}_{\mathrm{a}}$, ratio of helium-3 $\left({ }^{3} \mathrm{He}\right)$ to helium-4 $\left({ }^{4} \mathrm{He}\right)$ in the sample relative to the value in the atmosphere; --, not measured]

\begin{tabular}{|c|c|c|c|c|c|c|c|c|}
\hline $\begin{array}{c}\text { Site } \\
\text { name }\end{array}$ & $\begin{array}{c}\text { Well } \\
\text { ground } \\
\text { elevation }\end{array}$ & $\begin{array}{l}\text { Recharge } \\
\text { elevation }\end{array}$ & $\begin{array}{l}\text { Nitrogen } \\
\text { and argon } \\
\text { recharge } \\
\text { temperature }{ }^{1} \\
\left({ }^{\circ} \mathrm{C}\right)\end{array}$ & $\begin{array}{c}\text { Noble } \\
\text { gases } \\
\text { recharge } \\
\text { tempera- } \\
\text { ture }^{2}\left(\mathrm{~T}_{\mathrm{a}}\right) \\
\left({ }^{\circ} \mathrm{C}\right)\end{array}$ & $\begin{array}{c}\mathrm{Ae} \\
(\mathrm{ccSTP} / \mathrm{g})\end{array}$ & $\mathbf{F}$ & $\mathrm{Chi}^{2}$ & $\mathbf{R} / \mathbf{R}_{\mathbf{a}}$ \\
\hline VA-1A & 1,628 & 2,000 & 13.5 & 10.9 & 0.1262 & 0.95 & 0.05 & 0.80 \\
\hline VA-1B & 1,628 & 2,100 & 13.7 & 10.4 & 0.0008 & 0.04 & 0.04 & 0.74 \\
\hline VA-1C & 1,628 & 2,700 & 8.3 & 7.2 & 0.0068 & 0.21 & 0.00 & 0.75 \\
\hline TR-1C & 1,627 & 2,850 & 7.0 & 6.2 & 0.0034 & 0.47 & 0.02 & 0.74 \\
\hline $\mathrm{SO}-1 \mathrm{C}$ & 1,635 & 2,400 & 10.3 & 8.8 & 0.0015 & 0.00 & 0.19 & 0.73 \\
\hline SO-1D & 1,635 & 2,800 & 7.8 & 6.5 & 0.0069 & 0.58 & 0.00 & 0.74 \\
\hline $\mathrm{SO}-1 \mathrm{E}$ & 1,635 & 2,600 & 8.9 & -- & -- & -- & -- & -- \\
\hline RC-3 & ${ }^{3} 1,642$ & ${ }^{3} 2,150$ & 12.2 & -- & -- & -- & -- & -- \\
\hline RC-5 & ${ }^{3} 1,632$ & 32,500 & 9.2 & -- & -- & -- & -- & -- \\
\hline
\end{tabular}

${ }^{1}$ Weiss (1968).

${ }^{2}$ Aeschbach-Hertig and others (2000).

${ }^{3}$ NGVD 29. 


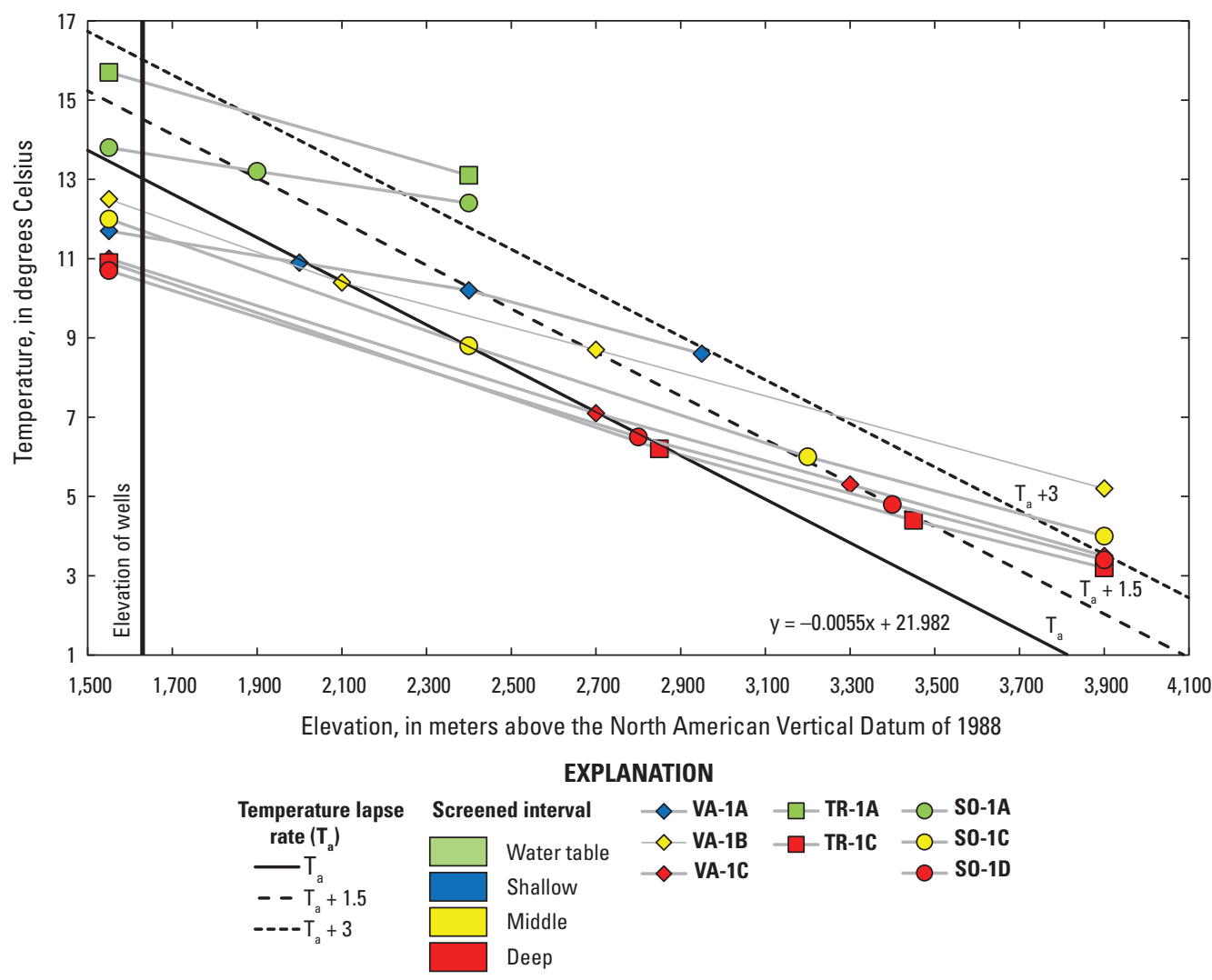

Figure 7. Noble gas recharge temperature and elevation.

TR-1A were not included in recharge temperature calculations because the model fits were higher than the $T_{a}$ equation (fig. 7); the data indicate warmer recharge temperatures for water from these wells.

The ratio $R / R_{a}$, where $R$ is the helium- 3 to helium- 4 ratio $\left({ }^{3} \mathrm{He} /{ }^{4} \mathrm{He}\right)$ of the sample and $\mathrm{R}_{\mathrm{a}}$ is the ${ }^{3} \mathrm{He} /{ }^{4} \mathrm{He}$ ratio of the present-day atmosphere $\left(1.38 \times 10^{-6}\right)$, indicates whether the source of helium gas is the atmosphere, crust, or mantle. $\mathrm{R} / \mathrm{R}_{\mathrm{a}}$ ratios from this study indicate groundwater has been in contact with crustal material for an appreciable amount of time because the values are less than 1 (White, 2013). Water likely did not enter the aquifer system recently as the $R / R_{a}$ ratios indicate recharge from deep sources.

The $\mathrm{N}_{2} /$ Ar ratio was determined for the Southern aquifertest pumping well (SO-1E) and the water-supply wells RC-3 and RC-5. Using Weiss (1968), approximate nitrogen and argon gas recharge temperatures were calculated (table 4). For RC-3, an approximate recharge temperature of $12.2{ }^{\circ} \mathrm{C}$ was calculated by using an input recharge elevation of 2,150 m above National Geodetic Vertical Datum of 1929, and for RC-5, an approximate recharge temperature of $9.2^{\circ} \mathrm{C}$ was calculated by using an input recharge elevation of $2,500 \mathrm{~m}$ above National Geodetic Vertical Datum of 1929. Recharge elevations for RC-3 and RC-5 were estimated from recharge elevations that were determined from the noble gas data analysis for the other samples. Where noble gas data were available, nitrogen and argon recharge temperatures using Weiss (1968) (table 4) were compared to the CE model values for noble gas recharge temperatures (Aeschbach-Hertig and others, 2000). The Weiss (1968) model predicted higher recharge temperatures than the $\mathrm{CE}$ model, which may indicate that the actual recharge temperatures for RC-3 and RC-5 are lower than calculated temperatures by a few degrees, as a full suite of noble gases is more robust than the $\mathrm{N}_{2} / \mathrm{Ar}$ ratio only.

The $\mathrm{N}_{2} /$ Ar ratio at SO-1E indicates a recharge elevation intermediate between SO-1C and SO-1D (table 4). Physical measurements of water input to the aquifer-test pumping wells (CC-1E and SO-1E) support the conclusion of Travis and Myers (2019) that the majority of water contributed to these wells is from the middle and deep zones.

\section{Carbon Isotopes}

In the sentinel wells, aquifer-test pumping wells, and water-supply wells, the $\delta^{13} \mathrm{C}$ values ranged from -7.81 to -9.59 (table 5) and varied little as a function of ${ }^{14} \mathrm{C}$, similar to the observations of Plummer and others (2012) for groundwater in the Middle Rio Grande Basin. The mean $\delta^{13} \mathrm{C}$ value (table 5) for groundwater from this study was $-8.76 \pm 0.42 \%$, which is similar to the $-8.2 \pm 1.4 \%$ mean for groundwater in the basin with radiocarbon ages of greater than 200 years 
(Plummer and others, 2012). Groundwater with a modern component of water had more depleted values of $\delta^{13} \mathrm{C}$, with a mean of $-11.9 \pm 2.0 \%$ (Plummer and others, 2012).

The $\delta^{13} \mathrm{C}$ and ${ }^{14} \mathrm{C}$ values were plotted (fig. 8) by using the graphical method of Han and Plummer (2016) to understand potential processes influencing carbon water chemistry. The "zero age" lines on figure 8 are determined by the ${ }^{14} \mathrm{C}$ and $\delta^{13} \mathrm{C}$ values of the soil gas and solid carbonate (Han and Plummer, 2016), and the area within these "zero age" lines is known as the "zero age" area. Samples from the water table and shallow sentinel wells plot within the "zero age" area, indicating that they have zero radiocarbon age, which may be explained by geochemical reaction with no radiocarbon decay. In contrast, Bexfield and others (2012) modeled groundwater from shallow and intermediate wells to have radiocarbon ages. The Han and Plummer (2016) graphical method can be biased to predict younger ages when plotting in the "zero age" area, as well as biased to predict older ages when plotting below the "zero age" area. However, the general ages indicated by the graphical method are indicative of the differing source waters in these wells.

Samples from the middle and deep sentinel wells, aquifer-test pumping wells, and water-supply wells plot in the region below the "zero age" area, indicating that they are old waters that have undergone ${ }^{14} \mathrm{C}$ decay (fig. 8; Han and others, 2012; Han and Plummer, 2016). Radiocarbon age was computed for samples having ${ }^{14} \mathrm{C}$ values less than $50 \mathrm{pmC}$ by using the revised F\&G solid ex model (11) in NetpathXL (Parkhurst and Charlton, 2008), which uses input values of $100 \mathrm{pmC}$ for soil gas and $0 \mathrm{pmC}$ for solid carbonate (Han and Plummer, 2013). To calculate the "zero age" line, a soil gas $\delta^{13} \mathrm{C}$ value of $-17 \%$ was used, which was the 75 th percentile of soil gas samples collected in the Middle Rio Grande Basin by Plummer and others (2012), and a solid carbonate value of $-4.45 \%$ was used, which was a mean solid carbonate value of samples collected from the Santa Fe Group in the Central Zone (Plummer and others, 2012, table C2). Radiocarbon ages were calculated for soil gas values of -12 and $-20 \%$, to provide a range of possible values, and a carbonate value of $-4.45 \%$; the range of values is presented in table 5 .

\section{Tritium}

Tritium is a useful tracer for determining if there is a component of water recharged during the period of nuclear bomb testing in the United States in the 1950s and 1960s, which released tritium into the atmosphere. The half-life of tritium is 12.32 years (Lucas and Unterweger, 2000), and tritium

Table 5. Results of tritium and carbon isotope analyses.

[Range of carbon ages derived from revised F\&G solid ex model (11) in NetpathXL (Parkhurst and Charlton, 2008). pCi/L, picocuries per liter; pmC, percent modern carbon; pM, percent modern; B.P., before present; NA, not applicable. Dates shown as month, day, year]

\begin{tabular}{|c|c|c|c|c|c|c|c|c|}
\hline Site name & Sample date & $\begin{array}{l}\text { Tritium } \\
\text { (pCi/L) }\end{array}$ & $\begin{array}{c}\text { Denormalized }{ }^{14} \mathrm{C} \\
\text { (pmC) }\end{array}$ & $\begin{array}{l}\text { Normalized } \\
{ }^{14} \mathrm{C}(\mathrm{pM})\end{array}$ & $\begin{array}{l}{ }^{14} \mathrm{C} \\
\text { error } \\
\text { (pM) }\end{array}$ & $\begin{array}{l}\delta^{13} \mathrm{C} \\
\text { (per } \\
\text { mil) }\end{array}$ & $\begin{array}{l}\text { Minimum cor- } \\
\text { rected age }\left(\delta^{13} \mathrm{C}\right. \\
\text { soil gas }-20) \text {, in } \\
\text { years } B . P .\end{array}$ & $\begin{array}{c}\text { Maximum cor- } \\
\text { rected age }\left(\delta^{13} \mathrm{C}\right. \\
\text { soil gas }-12), \text { in } \\
\text { years B.P. }\end{array}$ \\
\hline TR-1A & $5 / 22 / 2013$ & 0.16 & 58.59 & 57.1 & 0.17 & -8.71 & NA & NA \\
\hline TR-1B & $5 / 21 / 2013$ & NA & 26.27 & 25.6 & 0.13 & -8.93 & NA & 5,730 \\
\hline TR-1C & $5 / 20 / 2013$ & NA & 7.59 & 7.4 & 0.08 & -8.44 & 8,102 & 14,991 \\
\hline CC-1A & $6 / 4 / 2015$ & 0.84 & 62.47 & 60.8 & 0.25 & -7.81 & NA & $\mathrm{NA}$ \\
\hline CC-1B & 6/4/2015 & 0.07 & 56.54 & 55.1 & 0.15 & -8.15 & NA & NA \\
\hline $\mathrm{CC}-1 \mathrm{C}$ & $6 / 4 / 2015$ & -0.41 & 22.90 & 22.3 & 0.09 & -8.82 & 5 & 6,558 \\
\hline CC-1D & $6 / 11 / 2015$ & 0.06 & 15.30 & 14.9 & 0.08 & -8.38 & 2,013 & 9,108 \\
\hline CC-1E & $8 / 27 / 2015$ & NA & 13.60 & 13.3 & 0.08 & -8.42 & 2,472 & 10,095 \\
\hline SO-1A & $9 / 4 / 2015$ & 0.71 & 52.10 & 50.8 & 0.15 & -8.84 & NA & NA \\
\hline SO-1B & 9/9/2015 & 0 & 50.95 & 49.8 & 0.16 & -9.49 & NA & 1,396 \\
\hline $\mathrm{SO}-1 \mathrm{C}$ & $9 / 10 / 2015$ & 0.2 & 21.75 & 21.2 & 0.1 & -9.07 & 1,072 & 7,561 \\
\hline SO-1D & 9/10/2015 & 0.08 & 11.78 & 11.5 & 0.08 & -8.91 & 5,519 & 12,202 \\
\hline SO-1E & $9 / 11 / 2015$ & NA & 11.09 & 10.8 & 0.08 & -8.81 & 5,534 & 12,522 \\
\hline VA-1A & $2 / 7 / 2017$ & -0.08 & 57.12 & 55.7 & 0.15 & -8.81 & $\mathrm{NA}$ & NA \\
\hline VA-1B & 2/7/2017 & -0.17 & 29.39 & 28.7 & 0.11 & -8.79 & NA & 4,412 \\
\hline VA-1C & 2/7/2017 & -0.19 & 22.62 & 22.1 & 0.1 & -8.89 & 49 & 6,761 \\
\hline $\mathrm{RC}-3$ & $5 / 23 / 2013$ & NA & 36.86 & 36.0 & 0.2 & -9.59 & NA & 4,401 \\
\hline RC-5 & $5 / 23 / 2013$ & NA & 27.31 & 26.6 & 0.12 & -8.75 & NA & 4,975 \\
\hline
\end{tabular}




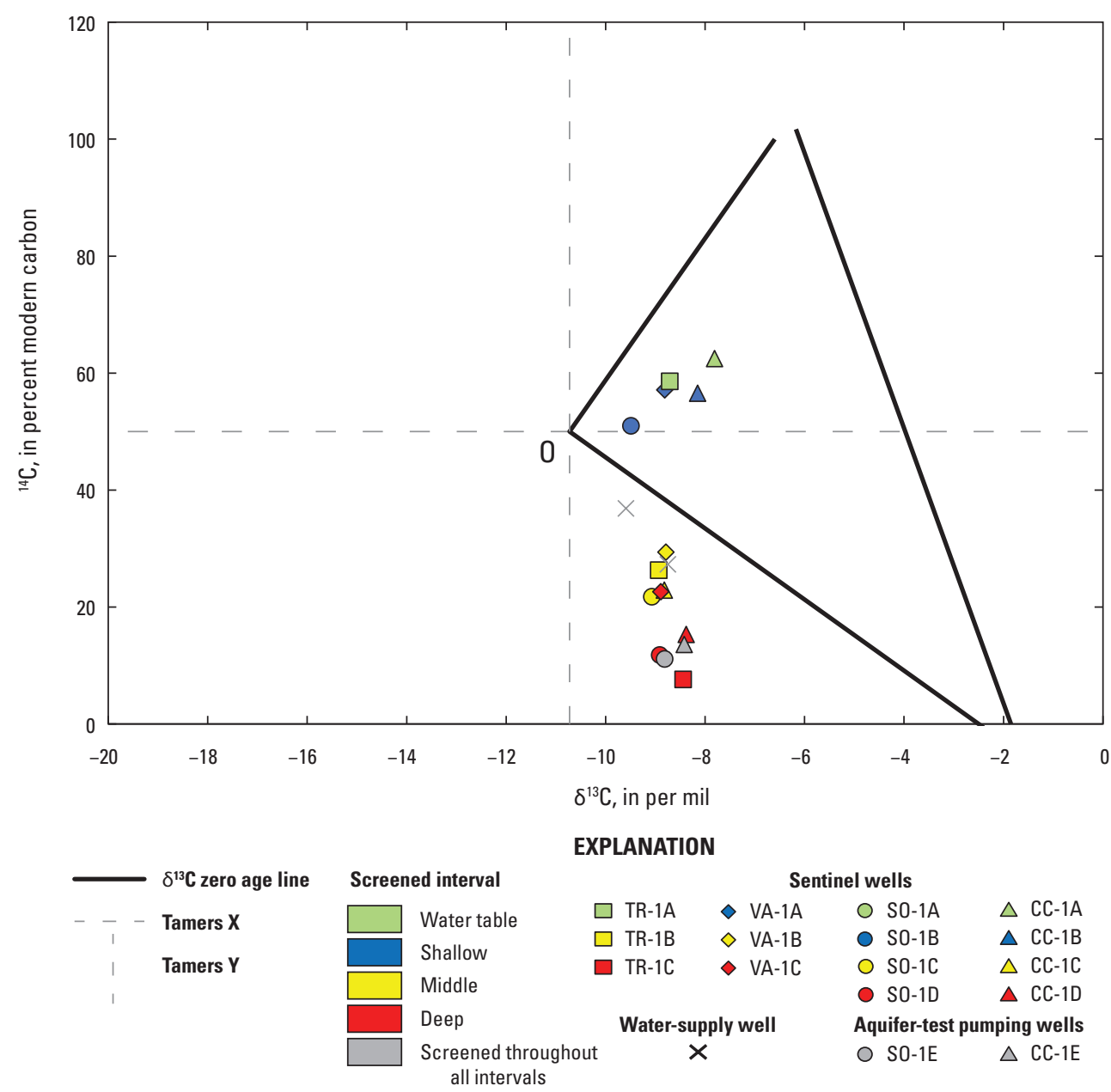

Figure 8. Carbon-14 $\left({ }^{14} \mathrm{C}\right)$ compared to isotopes of carbon $\left(\delta^{13} \mathrm{C}\right)$ in the sentinel wells, aquifer-test pumping wells, and water-supply wells. The "zero age" lines are determined by the ${ }^{14} \mathrm{C}$ and $\delta^{13} \mathrm{C}$ values of the soil gas and solid carbonate.

concentrations have been declining since the bomb testing. This flux of atmospheric tritium elevated the tritium concentrations in groundwater that was recharged after about 1953, relative to that which recharged prior to 1953 . As a result, groundwater tritium concentrations can qualitatively indicate groundwater age. Tritium concentrations in the samples ranged from less than detection to 0.84 picocurie per liter $(\mathrm{pCi} / \mathrm{L})($ table 5$)$. The concentrations are very low and indicate minimal to no presence of modern water (using a conservative threshold for modern water of $1.3 \mathrm{pCi} / \mathrm{L}$, which is equivalent to 4.19 tritium units [Beisner and others, 2017]). Tritium values were not available for samples from TR-1B and TR-1C, the aquifer-test pumping wells, or the water-supply wells.

\section{Chlorofluorocarbons}

CFCs were created in the 1930s, and CFC concentrations began to increase in the atmosphere starting in the 1940s. The presence of CFC compounds (CFC-11, CFC-12,
CFC-113) in water can indicate the contribution of water recharged after 1940. Additionally, the ratio of the CFC compounds has changed in the atmosphere over time, with the ratio of CFC-113/CFC-12 increasing during the 1980s. CFC results from wells in this study are summarized in table 6 . Concentration ranges were $0.011-2.075$ picomoles per kilogram (pmol/kg) for CFC-12, 0.034-1.722 pmol/kg for CFC-11, and $0.003-0.305 \mathrm{pmol} / \mathrm{kg}$ for CFC-113. The concentrations of CFC-113 (International Atomic Energy Agency, 2006) indicate a small percentage of modern water may be present at RC-3 and RC-5 (about 2-5 percent) and SO-1B and SO-1D (about $7-17$ percent) (table 6). The CFC-113/CFC-12 ratio indicates that the fraction of modern water at the wells has an approximate recharge year of 1977-82 for RC-3, 1985-88 for RC-5, 1984 for SO-1B, and 1979-80 for SO-1D. Two or more samples from these wells indicated the presence of modern water. Other samples from these wells did not have a possible ratio of CFC-113/CFC-12, assuming the compounds originated from air-equilibrated water, or only had one sample replicate that indicated a small presence (table 6). Contamination of 
Utilizing Indicators to Understand Groundwater Contribution to Wells Near Kirtland AFB, Albuquerque, N. Mex.

CFC samples by contact with the atmosphere may occur during sample collection and or storage; however, the ratio of CFC-113/CFC-12 in modern air at the time of sampling is unique compared to the ratio from the 1980s, so sampling errors or modification during storage are unlikely.

\section{Identification of Primary Zone of Contribution From Groundwater}

The identification of the primary zone of contribution of groundwater was the main goal of this study. Groundwater evolution is described in this section, as well as shifting groundwater flow direction and a comparison of hydrochemical zones of the groundwater.

\section{Groundwater Evolution}

The sentinel wells were constructed to monitor discrete intervals within the Santa Fe Group aquifer system that are the primary contributors of groundwater to water-supply wells; therefore, data from these wells can be used to determine the primary production zone(s) within the screened intervals of the supply wells. The Southern aquifer-test pumping well (SO-1E) is similar to the water-supply wells (RC-3, RC-4, and $\mathrm{RC}-5$ ) as, prior to grouting, it was screened through the water table (SO-1A), shallow (SO-1B), middle (SO-1C), and deep (SO-1D) aquifer zones (fig. 2, table 1). As the Southern sentinel well nest has the most complete dataset, the following discussion will focus on that well nest, along with data from SO-1E. Although the analytical data from the other sentinel well nests support the following discussion with similar conclusions, the results are not discussed in detail here. Thus, this discussion focuses on the evolution of groundwater at one well nest, although other well data are added to the discussion on occasion to provide stronger supporting evidence.

The major ion composition in the shallow well is different than in the water table, middle, deep, and aquifer-test pumping wells. In general, groundwater in the shallow well has higher percentages of bicarbonate, sodium, and potassium, and lower percentages of sulfate and calcium (fig. 3). Concentration ranges were also higher in the shallow and water table wells, including greater maximum concentrations of nitrate and sodium and lower silica and potassium than the middle and deep wells (fig. 4). To further differentiate groundwaters and to investigate potential ion sources, stochiometric relations were explored, including data from other sentinel well nests (fig. 9). Groundwater in the shallow wells at Southern (SO-1B) and VA (VA-1A) and water table wells at Trumbull (TR-1A) has distinctly higher sodium relative to chloride (fig. $9 A$ ). This may indicate (1) additional sodium input from cation exchange; (2) weathering of sodium aluminosilicates such as plagioclase $\left(\mathrm{NaAlSiO}_{3} \mathrm{O}_{8}\right.$; suggested by Plummer and others, 2012); or possibly (3) anthropogenic inputs such as sewer wastewater
(Panno and others, 2006). Given the higher silica content in the middle, deep, and aquifer-test pumping wells (fig. 4), anthropogenic inputs seem more likely to explain excess sodium in the shallow wells. Concentrations of arsenic, silica, and potassium are higher in the deeper wells, likely because of increased groundwater residence time (figs. 4 and 8) and the weathering of potassium feldspar and volcanic lithic fragments in the alluvium of the Santa Fe Group (Anderholm, 1988; Linhoff and others, 2016). Other potential sources of arsenic in the Middle Rio Grande Basin include adsorption/desorption processes involving iron oxides or mixing with mineralized water of deep origin (Bexfield and Plummer, 2003).

Waters influenced by carbonate dissolution are expected to plot along a 1:2 line (fig. 9B) of calcium plus magnesium versus bicarbonate (Drever, 1988). However, most waters plotted above this line, indicating that carbonate dissolution is not controlling the major ion chemistry of most wells sampled, except for the shallow wells. Relative to much of the Middle Rio Grande Basin, water in the water table and shallow wells has elevated nitrate concentrations (Plummer and others, 2012) potentially as a result of anthropogenic wastewater (Menció and others, 2016). Samples from the shallow and water table wells have distinctly higher $\mathrm{NO}_{3} / \mathrm{Na}$ ratios (fig. 9C) relative to the rest of the sampling suite, including samples from the water-supply wells. Samples from these shallow wells were oxygenated (fig. 4), implying that nitrate reduction likely is not presently occurring. The lower nitrate concentrations in the deeper wells may be due to more reducing conditions (fig. 4), which would promote nitrate reduction and removal. The elevated nitrate in the shallow aquifer likely has an anthropogenic source such as leaky infrastructure, irrigation, or both (Roy and others, 1999; Menció and others, 2016). Chloride to bromide (chloride/bromide) ratios can be indicative of solute sources (Davis and others, 1998) and could be used to differentiate shallow from deeper wells. Samples from water table wells have chloride/bromide ratios of 73 to 127 (fig. 10), and samples from shallow wells have a slightly higher range of ratios, generally ranging from 73 to 210 , with one well (CC-1B) having a chloride/bromide ratio of 303. The chloride concentrations range from 8 to $68 \mathrm{mg} / \mathrm{L}$ in the water table and shallow wells. The lower chloride/bromide ratios in the water table and shallow groundwater is likely due to surface recharge bringing solutes from the unsaturated zone (Bexfield and others, 2012). The lower chloride/bromide ratios could also indicate a nonseptic wastewater source (Davis and others, 1998), although this ratio is not always a reliable tracer of anthropogenic wastewater (Panno and others, 2006). The chloride/bromide ratios are higher in the middle, deep, aquifer-test pumping, and water-supply wells, ranging from 173 to 413, and the chloride concentrations are slightly higher, on average, than the other wells, ranging from 23 to $69 \mathrm{mg} / \mathrm{L}$. These values are similar to the ratios and concentrations for deep wells as reported by Bexfield and others (2012), who suggested that the results could reflect a fraction of relatively mineralized groundwater from a deep source. Water from aquifer-test pumping wells and water-supply wells 





Utilizing Indicators to Understand Groundwater Contribution to Wells Near Kirtland AFB, Albuquerque, N. Mex.

is more similar to water from middle and deep sentinel wells than water from water table or shallow sentinel wells (fig. 10). Water obtained from aquifer-test pumping wells in 2016, after the deeper portion of their screens had been plugged, moved from the upper to the middle range of values for the chloride/ bromide ratios and for chloride concentrations.

Stable isotopes $\left(\delta^{2} \mathrm{H}\right.$ and $\left.\delta^{18} \mathrm{O}\right)$ often reflect conditions of groundwater recharge as the isotopes in atmospheric moisture systematically change via Rayleigh distillation as air masses move away from source areas and cool and condense to precipitate as rain or snow (Craig, 1961; Rozanski and others, 1993). For the Southern sentinel well nest, stable isotopes were most depleted in the middle and deep wells, ranging from -91.6 to $-96.9 \% \delta^{2} \mathrm{H}$ (fig. 5). The depletion is indicative of recharge by seepage from the Rio Grande, which is sourced from high-elevation snowmelt. Stable isotopes in the shallow and water table wells were less depleted, ranging from -79.6 to $-82.6 \% \delta^{2} \mathrm{H}$ (fig. 5), indicating likely recharge from the mountain front. The aquifer-test pumping well was sampled in 2015 and in 2016, before and after the well was grouted to a shallower depth which closed off the deeper portion of the well screen. Stable isotopes were substantially less depleted in the sample from $2016\left(-87.4 \% 0 \delta^{2} \mathrm{H}\right)$ relative to the sample from $2015\left(-96.6 \% \delta^{2} \mathrm{H}\right)$, consistent with the removal of a substantial contribution of water from deeper zones at this site. This is only the case with the Southern wells. Stable isotopes in the other shallow and water table sentinel wells are more depleted, indicating recharge from the Rio Grande, and supporting the conclusion that the study area is likely near a transition in recharge sources.

Recharge temperature calculated by using the CE model (Aeschbach-Hertig and others, 2000) indicated that the deep well (SO-1D) has a cooler recharge temperature of $6.5^{\circ} \mathrm{C}$ relative to the middle well, which had a warmer recharge temperature of $8.8^{\circ} \mathrm{C}$ (table 4 ). These results were supported by the analysis of nitrogen and argon using the Weiss model (Weiss, 1968). Although the Weiss model predicted warmer temperatures than the CE model, the Weiss model nitrogen and argon gas recharge temperatures (table 4) were still cooler for the deep well $\left(7.8^{\circ} \mathrm{C}\right)$ than the middle well $(10.3$ ${ }^{\circ} \mathrm{C}$ ). Additionally, a Weiss model temperature of $8.9^{\circ} \mathrm{C}$ was calculated for groundwater in the aquifer-test pumping well, which is cooler than in the middle well but warmer than in the deep well.

Carbon isotope analysis indicated that the water table and shallow wells produced relatively young waters having no radiocarbon decay, and the middle, deep, and aquifer-test pumping wells produced older waters (fig. 8). Tritium concentrations were very low and indicated a minimal or nonexistent component of modern water for all the wells. CFC-113/ CFC-12 ratios for SO-1B and SO-1D indicated that there may be a small amount of modern water present.

Although there appear to be distinct differences in the sources and ages of groundwater from the sentinel wells screened above (water table, shallow), between (middle) and below (deep) the confining A1 and A2 clay units, the aquifer-test pumping well provides a unique opportunity to evaluate which interval is the most productive to a well screened through all of the intervals (water table, shallow, middle, and deep), and to demonstrate how the chemistry of groundwater produced by a well can change after grouting to a shallower depth in the middle interval. Under pumping conditions, flow logging indicated that the aquifer-test pumping well draws 65 percent of its total flow into the well from below the A1 unit and 18 percent from between the A1 and A2 units (Travis and Myers, 2019). The aquifer-test pumping well data indicated that the well, which is constructed similarly to the water-supply wells, is likely pulling more water from the middle and deep intervals than from the shallow interval but is also likely a mix of the waters from all of the intervals.

\section{Determining Primary Aquifer Zones Contributing to Water-Supply Wells}

By comparing geochemical, isotopic, and age data collected at the nearby sentinel wells to data collected from the water-supply wells in the late 1990s and in 2013, the source of groundwater being withdrawn by the water-supply wells (RC-3, RC-4, and RC-5) can be inferred. Table 7 provides a summary of the conclusions reached regarding recharge sources and groundwater age based on analytical results.

The dominant cation in the water-supply wells is calcium, and the dominant anion is bicarbonate, but the bicarbonate in the water-supply wells was not as high as the bicarbonate in the shallow wells and was more similar to the bicarbonate in the middle and deep sentinel wells and aquifer-test pumping wells (fig. 3). Ranges in water-supply wells for some trace elements and major ions, including arsenic, and potassium, are more similar to the ranges found in the water table, shallow, and middle sentinel wells than in the deep wells (fig. 4). There is little to no nitrate present in the water-supply wells, and the chloride/bromide ratios are similar to those in the middle and deep sentinel wells and aquifer-test pumping wells (fig. 10).

Stable isotope data collected from the water-supply wells in the late 1990s by Plummer and others (2012) indicated that RC-3 was located at an isotopic shift from mountain-front recharge $\left(-80\right.$ to $\left.-85 \% 0 \delta^{2} \mathrm{H}\right)$ to Rio Grande seepage recharge $\left(-90\right.$ to $-100 \%$ o $\left.\delta^{2} \mathrm{H}\right)$ (fig. 6). The 2013 stable isotope data from RC-3 indicated that those lines of equal $\delta^{2} \mathrm{H}$ composition (fig. 6) may be shifting, as groundwater from RC-3 has become more depleted (fig. 5), which indicates that the recharge source may be shifting from primarily the mountain front $\left(-85.9 \% \delta^{2} \mathrm{H}\right.$ in 1996$)$ to the Rio Grande $(-90.5 \%$ $\delta^{2} \mathrm{H}$ in 2013). In general, the middle and deep sentinel wells and aquifer-test pumping wells and RC-4 and RC-5 were more depleted than mountain front recharge (fig. 5), indicating the Rio Grande is the primary recharge source for those wells. The Southern water table and shallow wells, as well as RC-3, may still be near a transition in recharge sources (mountain-front recharge versus Rio Grande seepage recharge; fig. 6), and recharge source may not be a clear indicator of 

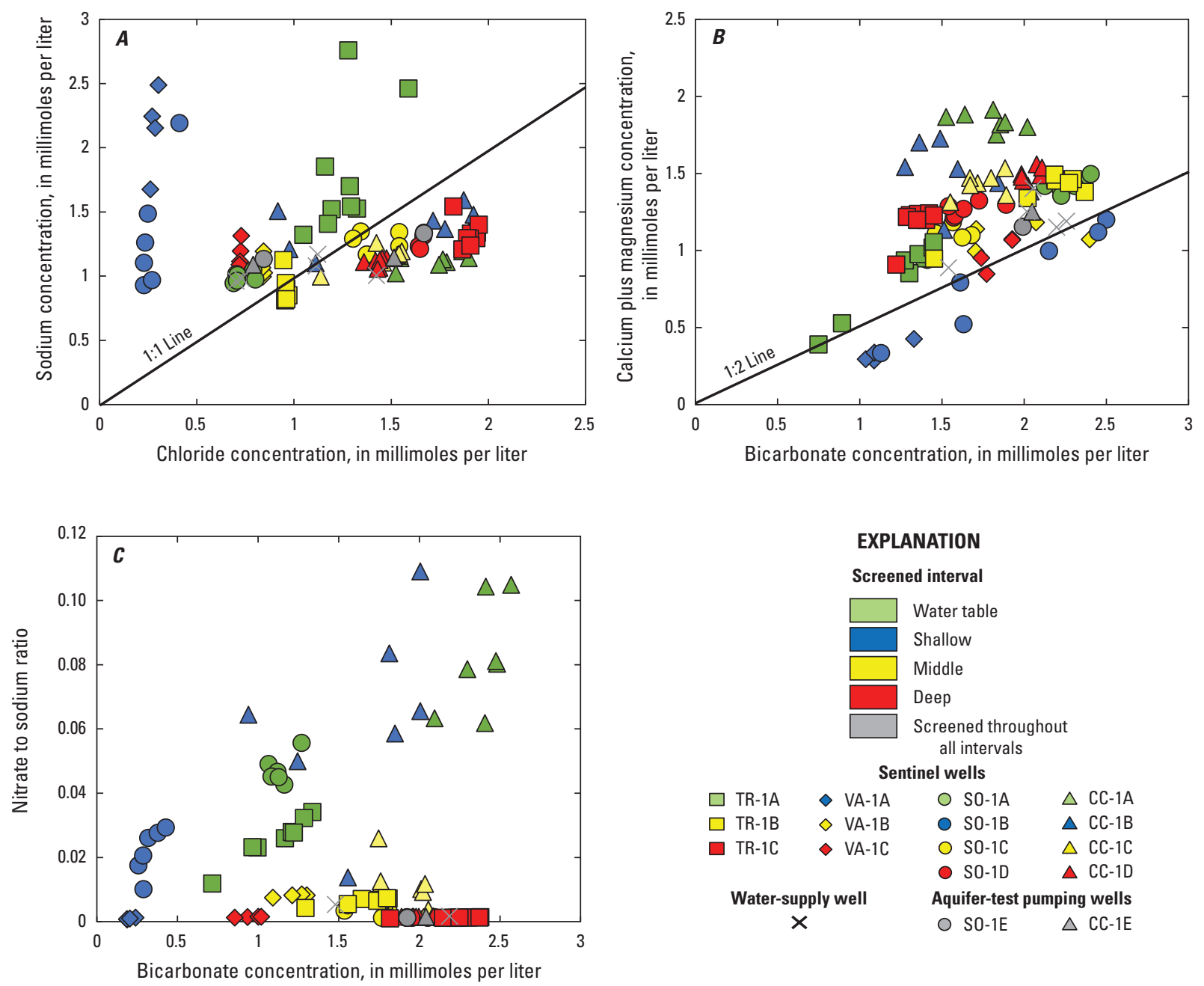

Figure 9. Stoichiometric plots of groundwater samples. Elemental ratios were all calculated using molarity.

the source of water to the water-supply wells in this area of shifting recharge sources. Dissolved nitrogen and argon gas were analyzed in groundwater from RC-3 and RC-5, and the recharge temperatures, using the Weiss (1968) model, were calculated as $12.2{ }^{\circ} \mathrm{C}$ for RC-3 and $9.2^{\circ} \mathrm{C}$ for RC-5 (table 4 ). Where the recharge temperature for RC-5 is more aligned with the Southern middle, deep, and aquifer-test pumping wells, the recharge temperature of RC-3 is similar to the warmer recharge temperatures modeled in the VA-1A (shallow) and VA-1B (middle) sentinel wells. Although the VA wells are farther from the water-supply wells, it could be an indicator that the water-supply wells are mixing shallow and deeper waters. Carbon isotope analysis for wells RC-3 and RC-5 indicated that the water-supply wells are dominated by old waters that have undergone ${ }^{14} \mathrm{C}$ decay (fig. 8, table 5) and are similar to the middle and deep sentinel wells and the aquifer-test pumping wells.

The borehole flow-logging data from Bexfield and others (2012), collected in a well located approximately $5,630 \mathrm{~m}$ west of the sentinel well study area, indicated that the upper intervals contributed the most water to that water-supply well, but Travis and Myers (2019) showed that the deeper intervals were contributing the most water to the aquifer-test pumping wells of this study. The results of the current study indicate that the water-supply wells within the study area produce groundwater from multiple intervals in each well and also that they likely produce more groundwater from the deeper intervals that are below the extent of the EDB plume (USACE, 2017). Given that carbon isotope data indicate the groundwater is older and has undergone ${ }^{14} \mathrm{C}$ decay, the amount of young water in the water-supply wells, which CFCs indicate is present in the water table and shallow wells, is likely minimal.

\section{Shifting Groundwater Directions and the Comparison of Hydrochemical Zones of the Water}

Plummer and others (2012) delineated hydrochemical zones in the Middle Rio Grande Basin. Each of these hydrochemical zones were characterized by groundwater that was distinctly different from the other zones in chemical 


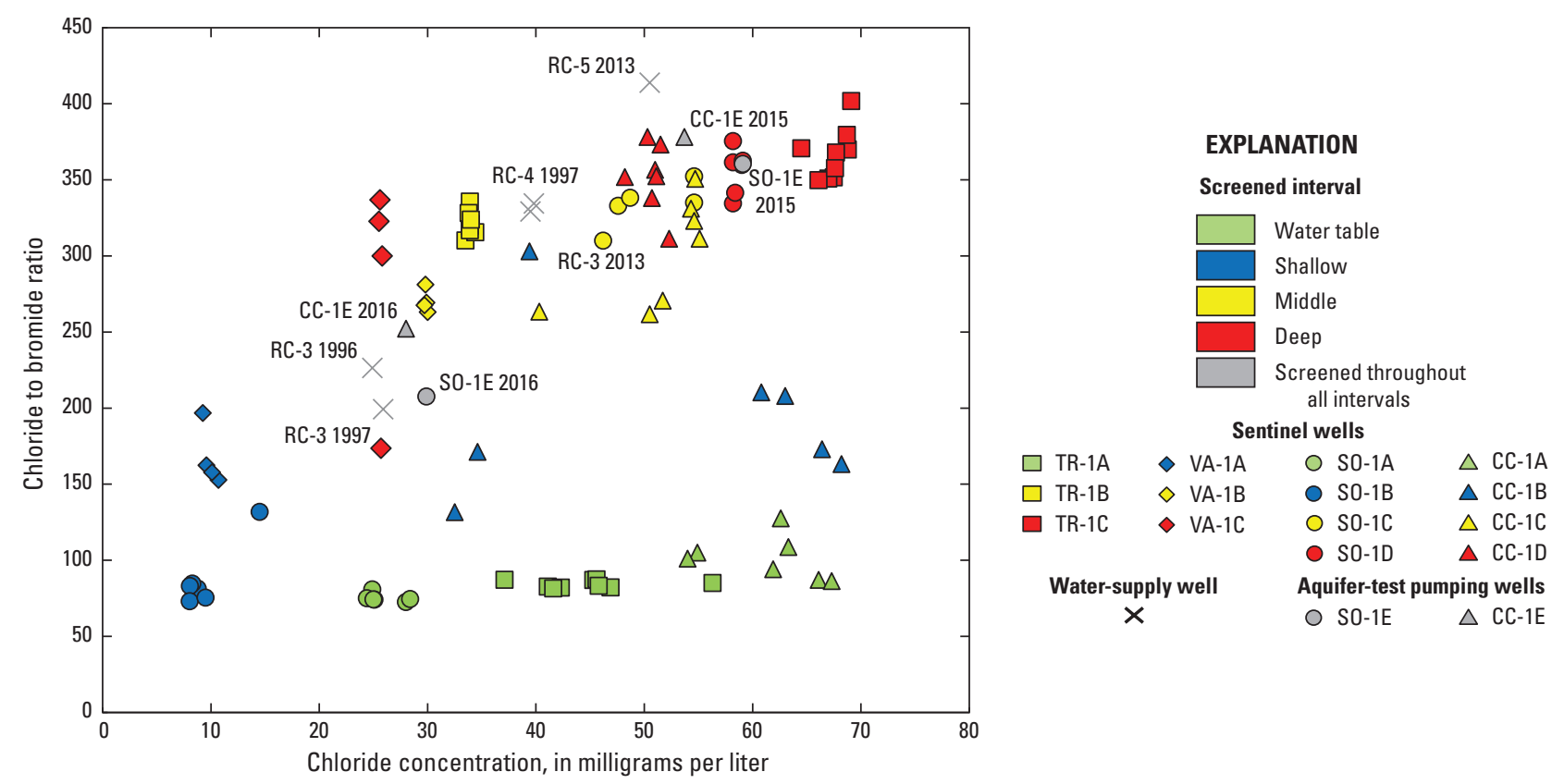

Figure 10. Chloride to bromide ratio compared to concentrations of chloride (modified from Travis and Myers, 2019) for sentinel wells, aquifer-test pumping wells, and water-supply wells.

and isotopic character. The Eastern Mountain-Front zone is characterized by groundwater consistent with precipitationdriven infiltration, calcium and bicarbonate dominant water, low concentrations of minor elements, less depleted $\delta^{2} \mathrm{H}$ (median value of $-81.0 \%$ ), and lower ${ }^{14} \mathrm{C}$ activity (median value of $47.2 \mathrm{pmC}$ ). The Central zone has calcium (or mixed cation) and bicarbonate dominant water, as well as elevated concentrations of potassium and silica; the $\delta^{2} \mathrm{H}$ (median value of -95.4\%o) is lighter and indicative of Rio Grande seepage recharge, and the ${ }^{14} \mathrm{C}$ activity is higher (median value of $61.0 \mathrm{pmC})$.

The study area is in two of the hydrochemical zones delineated in Plummer and others (2012), and the sentinel well nests and water-supply well locations are divided by these two zones (fig. 6). The Trumbull, Cesar Chavez, and VA sentinel wells and water-supply well RC-5 are located in the Central hydrochemical zone. Water-supply well RC-3 is located in the Eastern Mountain-Front hydrochemical zone. Water-supply well RC-4 and the Southern sentinel wells are very near the line between the Central and Eastern Mountain-Front zones. The study area extends across the relatively steep gradient in stable isotopes that helped to define the hydrochemical zones (fig. 6). In a previous study (Bexfield and Anderholm, 2002), groundwater in several wells (including RC-4 and RC-5) in the Central zone located just north of KAFB was noted to have an unusual chemical composition and higher chloride concentrations, which were thought to be due to upwelling of mineralized water deep in the aquifer system.

Recent studies have shown that although groundwater flow in the Santa Fe Group is generally southward, near the BFF, historical pumping by water-supply wells caused groundwater to flow to the northeast toward lower water levels starting in about 1980 (Powell and McKean, 2014; Rice and others, 2014). In 2008, groundwater pumping decreased as surface water was used to supplement the Albuquerque water supply, and since that time, groundwater levels in southeastern Albuquerque have been rising (Powell and McKean, 2014). Ritchie and others (2019) calculated that since 2008, water levels have risen in the study area anywhere from 6.1 to $9.1 \mathrm{~m}$. With the increase in water levels and shifts in groundwater flow direction, the hydrochemical zones and lines of equal isotopic composition could be shifting, as indicated by the recent results for RC-3. With the rise in groundwater levels and the shifting groundwater flow directions resulting from reduced pumping for municipal supply, additional sampling may be beneficial to better understand changes occurring in the groundwater system. 
Table 7. Summary of anthropogenic inputs, recharge sources, and groundwater age at the wells included in this study.

[CFCs, chlorofluorocarbons; NA, data not available; \%, percent; ${ }^{\circ} \mathrm{C}$, degree Celsius; \%o, per mil]

\begin{tabular}{|c|c|c|c|c|c|c|}
\hline \multirow{2}{*}{$\begin{array}{c}\text { Site } \\
\text { name }\end{array}$} & \multicolumn{3}{|c|}{ Recharge temperature and source } & \multicolumn{3}{|c|}{ Groundwater age } \\
\hline & Noble gases ${ }^{1}$ & $\begin{array}{l}\text { Nitrogen and } \\
\text { argon gas }^{2}\end{array}$ & Stable isotopes ${ }^{3}$ & Carbon isotopes ${ }^{4}$ & $\mathrm{CFCs}^{5}$ & Tritium $^{6}$ \\
\hline TR-1A & NA & NA & Lighter & Zero radiocarbon age & Not probable & Pre-modern \\
\hline TR-1B & NA & NA & Lighter & Radiocarbon decay & Not probable & NA \\
\hline TR-1C & Cooler & Cooler & Lighter & Radiocarbon decay & Not probable & NA \\
\hline $\mathrm{CC}-1 \mathrm{~A}$ & NA & NA & Lighter & Zero radiocarbon age & Not probable & Pre-modern \\
\hline $\mathrm{CC}-1 \mathrm{~B}$ & NA & NA & Lighter & Zero radiocarbon age & Not probable & Pre-modern \\
\hline $\mathrm{CC}-1 \mathrm{C}$ & NA & NA & Lighter & Radiocarbon decay & Not probable & Pre-modern \\
\hline CC-1D & NA & NA & Lighter & Radiocarbon decay & Not probable & Pre-modern \\
\hline $\mathrm{CC}-1 \mathrm{E}$ & NA & NA & Lighter & Radiocarbon decay & NA & NA \\
\hline SO-1A & NA & NA & Heavier & Zero radiocarbon age & Not probable & Pre-modern \\
\hline SO-1B & NA & NA & Heavier & Zero radiocarbon age & $\begin{array}{l}\text { Mixture } \\
\quad(14.7-15.1 \%)\end{array}$ & Pre-modern \\
\hline $\mathrm{SO}-1 \mathrm{C}$ & Cooler & Cooler & Lighter & Radiocarbon decay & Not probable & Pre-modern \\
\hline SO-1D & Cooler & Cooler & Lighter & Radiocarbon decay & $\begin{array}{l}\text { Mixture } \\
\quad(7.4-17.1 \%)\end{array}$ & Pre-modern \\
\hline SO-1E & NA & Cooler & $\begin{array}{l}\text { Shifting from lighter }(2015) \\
\text { to heavier }(2016, \text { after } \\
\text { changing screened interval) }\end{array}$ & Radiocarbon decay & NA & NA \\
\hline VA-1A & Warmer & Warmer & Lighter & Zero radiocarbon age & Not probable & Pre-modern \\
\hline VA-1B & Warmer & Warmer & Lighter & Radiocarbon decay & Not probable & Pre-modern \\
\hline VA-1C & Cooler & Cooler & Lighter & Radiocarbon decay & Not probable & Pre-modern \\
\hline $\mathrm{RC}-3$ & NA & Warmer & $\begin{array}{l}\text { Shifting from heavier (1996) } \\
\text { to lighter (2013) }\end{array}$ & Radiocarbon decay & Mixture (3.0-4.6\%) & NA \\
\hline $\mathrm{RC}-4$ & NA & NA & Lighter & NA & NA & NA \\
\hline $\mathrm{RC}-5$ & NA & Cooler & Lighter & Radiocarbon decay & $\begin{array}{l}\text { Mixture } \\
\quad(7.4-17.1 \%)\end{array}$ & NA \\
\hline
\end{tabular}

${ }^{1}$ Noble gas thresholds: Warmer-Recharge temperatures were greater than $10^{\circ} \mathrm{C}$. Cooler-Recharge temperatures were less than $10{ }^{\circ} \mathrm{C}$.

${ }^{2}$ Nitrogen and argon gas thresholds: Warmer—Recharge temperatures were greater than $12{ }^{\circ} \mathrm{C}$. Cooler-Recharge temperatures were less than $12{ }^{\circ} \mathrm{C}$.

${ }^{3}$ Stable isotope thresholds: Lighter - stable isotope of hydrogen $\left(\delta^{2} \mathrm{H}\right)$ ranges from -90 to $-100 \%$ indicate recharge from the Rio Grande, which is sourced by cooler, higher-elevation snowmelt from Colorado and northern New Mexico (Plummer and others, 2012). Heavier- $\delta^{2} \mathrm{H}$ ranges from -80 to $-85 \%$ indicate warmer, lower-elevation mountain-front recharge from the Sandia Mountains (Plummer and others, 2012).

${ }^{4}$ Carbon isotopes: Zero radiocarbon age—Results indicated zero radiocarbon age. Mixture—Results indicated a mixture containing some radiocarbon decay. Radiocarbon decay—Results indicated older waters that have undergone radiocarbon decay.

${ }^{5}$ CFCs: No probable ratio-Samples did not have a probable ratio of CFC-113/CFC-12 or only had one sample replicate that indicated a small percentage Mixture (including percentage range) — Wells had two or more samples which indicated a small percentage of modern water younger than 1979.

${ }^{6}$ Tritium: Pre-modern-Majority of water was older than 1952.

\section{Summary}

In 1999, a jet-fuels release was discovered at the Bulk Fuels Facility (BFF) on Kirtland Air Force Base (KAFB), Albuquerque, New Mexico. Contaminants had reached the water table and migrated north-northeast toward water-supply wells. The objective of sampling sentinel wells installed downgradient from the KAFB BFF was to determine the primary zone(s) of groundwater production to water-supply wells in the vicinity, for comparison with groundwater documented to be affected by the BFF jet-fuels release. The sentinel wells are screened within the Santa Fe Group aquifer system, which includes the low permeability A1 and A2 clay units. The sentinel wells are categorized as water table, shallow, middle, and deep. The aquifer-test pumping wells and water-supply wells are screened across multiple water-bearing units within the Santa Fe Group, including above and below the A1 and A2 
clay units. Wells were sampled for major ions, trace elements, stable isotopes, dissolved gases, tritium, carbon isotopes, and chlorofluorocarbons.

Evapotranspiration, land-use practices, water sources, and groundwater flow paths likely explain geochemical variations observed between varying aquifer depths in the Middle Rio Grande Basin. The general chemical composition of groundwater from all but two shallow wells was predominantly calcium and bicarbonate/carbonate. Groundwater in the Veteran's Administration (VA) and Southern shallow sentinel wells was more dominated by sodium and bicarbonate/carbonate. Relative to the shallow and water table wells, the middle and deep sentinel wells and aquifer-test pumping wells generally had evidence of longer groundwater residence times within the aquifer and had higher concentrations of trace elements resulting from weathering of materials in the aquifer system. Concentrations of arsenic, silica, and potassium were higher in the middle and deep sentinel wells and the aquifer-test pumping wells than in the shallow and water table wells. Samples from the shallow and water table wells had higher concentrations of nitrate than those from the deeper wells. The chloride/ bromide ratios in the shallow and water table wells were lower than the middle, deep, aquifer-test pumping, and water-supply wells, perhaps indicating different solute sources for the shallower wells. The stable isotopes were more depleted, indicating recharge originating as seepage from the Rio Grande, in the middle, deep, aquifer-test pumping, and water-supply wells compared with the shallower wells. However, the study area is located near a shift from river seepage recharge to mountain-front recharge. Therefore, Southern water table and shallow wells, along with RC-3, may be receiving mountainfront recharge, which is less depleted in stable isotopes than recharge from the Rio Grande. Dissolved gas data indicated that the middle, deep, and aquifer-test pumping wells had lower recharge temperatures than the water table and shallow wells. The water-supply wells had recharge temperatures that were similar to those in the middle and deeper wells. Carbon isotopes indicated water was older in the middle, deep, aquifer-test pumping, and water-supply wells than in the shallow sentinel wells.

The ratio of nitrogen to argon $\left(\mathrm{N}_{2} / \mathrm{Ar}\right)$, carbon and stable isotopes and results of past flow-logging analysis indicate the water-supply wells likely produce groundwater from the middle and deeper portions of the aquifer system that are below the A2 clay unit. However, some of the geochemical data indicate that there may be some modern water with a shorter residence time entering the wells. With the rise in groundwater levels and the shifting groundwater flow directions resulting from reduced pumping for municipal supply, additional sampling may be beneficial to better understand changes occurring in the groundwater system.

\section{References Cited}

Aeschbach-Hertig, W., Peeters, F., Beyerle, U., and Kipfer, R., 1999, Interpretation of dissolved atmospheric noble gases in natural waters: Water Resources Research, v. 35, no. 9, p. 2779-2792, accessed February 23, 2021, at https://doi.org/10.1029/1999WR900130.

Aeschbach-Hertig, W., Peeters, F., Beyerle, U., and Kipfer, R., 2000, Palaeotemperature reconstruction from noble gases in ground water taking into account equilibration with entrapped air: Nature, v. 405, no. 6790 , p. $1040-1044$, accessed February 23, 2021, at https://doi.org/10.1038/ 35016542 .

Anderholm, S.K., 1988, Ground-water geochemistry of the Albuquerque-Belen Basin, central New Mexico: U.S. Geological Survey Scientific Investigations Report 86-4094, 110 p., accessed February 23, 2021, at https://doi.org/10.3133/wri864094.

Ballentine, C.J., and Hall, C.M., 1999, Determining paleotemperature and other variables by using an errorweighted, nonlinear inversion of noble gas concentrations in water: Geochimica et Cosmochimica Acta, v. 63, no. 16, p. 2315-2336, accessed February 23, 2021, at https://doi.org/10.1016/S0016-7037(99)00131-3.

Beisner, K.R., Tillman, F.D., Anderson, J.R., Antweiler, R.C., and Bills, D.J., 2017, Geochemical characterization of groundwater discharging from springs north of the Grand Canyon, Arizona, 2009-2016: U.S. Geological Survey Scientific Investigations Report 2017-5068, 58 p., accessed February 23, 2021, at https://doi.org/10.3133/sir20175068.

Bell, M.T., Ferguson, C., and Brown, J.E., 2018, Description of groundwater monitoring wells installed at and near Kirtland Air Force Base, Albuquerque, New Mexico, 2013-2016 (ver. 1.2, May 2019): U.S. Geological Survey Data Release, accessed February 23, 2021, at https://doi.org/ 10.5066/F7NV9HHG.

Bexfield, L.M., and Anderholm, S.K., 2002, Spatial patterns and temporal variability in water quality from City of Albuquerque drinking-water supply wells and piezometer nests, with implications for the groundwater flow system: U.S. Geological Survey Water-Resources Investigations Report 01-4244, 110 p., accessed February 23, 2021, at https://doi.org/10.3133/wri014244.

Bexfield, L.M., Jurgens, B.C., Crilley, D.M., and Christenson, S.C., 2012, Hydrogeology, water chemistry, and transport processes in the zone of contribution of a public-supply well in Albuquerque, New Mexico, 2007-9: U.S. Geological Survey Scientific Investigations Report, 2011-5182, 109 p., accessed February 23, 2021, at https://doi.org/10.3133/ sir20115182. 
Bexfield, L.M., Lindberg, W.E., and Anderholm, S.K., 1999, Summary of water-quality data for City of Albuquerque drinking-water supply wells, 1988-97: U.S. Geological Survey Open-File Report 99-195, 144 p., accessed February 23, 2021, at https://doi.org/10.3133/ofr99195.

Bexfield, L.M., and Plummer, L.N., 2003, Occurrence of arsenic in ground water of the Middle Rio Grande Basin, central New Mexico, chap. 11 of Welch, A.H., and Stollenwerk, K.G., eds., Arsenic in ground water-Geochemistry and occurrence: Boston, Kluwer Academic Publishers, p. 295-327, accessed September 1, 2021, at https://doi.org/ 10.1007/0-306-47956-7_11.

Busenberg, E., and Plummer, L.N., 1992, Use of chlorofluorocarbons $\left(\mathrm{CCl}_{3} \mathrm{~F}\right.$ and $\left.\mathrm{CCl}_{2} \mathrm{~F}_{2}\right)$ as hydrologic tracers and age-dating tools - The alluvium and terrace system of central Oklahoma: Water Resources Research, v. 28, no. 9, p. 2257-2283, accessed February 23, 2021, at https://doi.org/10.1029/92WR01263.

Busenberg, E., and Plummer, L.N., 2010, A rapid method for the measurement of sulfur hexafluoride $\left(\mathrm{SF}_{6}\right)$, trifluoromethyl sulfur pentafluoride $\left(\mathrm{SF}_{5} \mathrm{CF}_{3}\right)$, and Halon $1211\left(\mathrm{CF}_{2} \mathrm{ClBr}\right)$ in hydrologic tracer studies: Geochemistry Geophysics Geosystems, v. 11, no. 11, p. n/a, accessed February 23, 2021, at https://doi.org/10.1029/ 2010 GC003312.

Cey, B.D., 2009, On the accuracy of noble gas recharge temperatures as a paleoclimate proxy: Journal of Geophysical Research, v. 114, no. D4, no. D4, D04107, accessed February 23, 2021, at https://doi.org/10.1029/ 2008JD010438.

Connell, S.D., 2006, Preliminary geologic map of the Albuquerque-Rio Rancho metropolitan area and vicinity, Bernalillo and Sandoval Counties, New Mexico: New Mexico Bureau of Geology and Mineral Resources Open-File Report 496, 2 sheets, scale 1:50,000, accessed February 23, 2021, at https://geoinfo.nmt.edu/publications/ openfile/details.cfml? Volume $=496$.

Connell, S.D., Allen, B.D., and Hawley, J.W., 1998, Subsurface stratigraphy of the Santa Fe Group from borehole geophysical logs, Albuquerque area, New Mexico: New Mexico Geology, v. 20, no. 1, p. 2-7, accessed February 23, 2021, at https://geoinfo.nmt.edu/publications/ periodicals/nmg/20/n1/nmg_v20_n1_p2.pdf.

Craig, H., 1961, Isotopic variations in meteoric waters: Science, v. 133, no. 3465, p. 1702-1703, accessed February 23, 2021, at https://doi.org/10.1126/science.133 .3465 .1702 .
Davis, S.N., Whittemore, D.O., and Fabryka-Martin, J., 1998, Uses of chloride/bromide ratios in studies of potable water: Ground Water, v. 36, no. 2, p. 338-350, accessed February 23, 2021, at https://doi.org/10.1111/j.17456584.1998.tb01099.x.

Domenico, P.A., and Schwartz, F.A., 1990, Physical and chemical hydrogeology: New York, Wiley, 824 p.

Drever, J.I., 1988, The geochemistry of natural waters: Englewood Cliffs, N.J., Prentice Hall, 437 p.

Fishman, M.J., ed., 1993, Methods of analysis by the U.S. Geological Survey National Water Quality LaboratoryDetermination of inorganic and organic constituents in water and fluvial sediments: U.S. Geological Survey OpenFile Report 93-125, 217 p., accessed February 23, 2021, at https://doi.org/10.3133/ofr93125.

Fishman, M.J., and Friedman, L.C., 1989, Methods for determination of inorganic substances in water and fluvial sediments: U.S. Geological Survey Techniques of Water-Resources Investigations, book 5, chap. A1, 545 p., accessed February 23, 2021, at https://doi.org/10.3133/ twri05A1.

Galanter, A.E., and Curry, L.T.S., 2019, Estimated 2016 groundwater level and drawdown from predevelopment to 2016 in the Santa Fe Group aquifer system in the Albuquerque area, central New Mexico: U.S. Geological Survey Scientific Investigations Map 3433, 1 sheet, 13-p. pamphlet, accessed February 22, 2021, at https://doi.org/ $10.3133 / \operatorname{sim} 3433$.

Garbarino, J.R., 1999, Methods of analysis by the U.S. Geological Survey National Water Quality LaboratoryDetermination of dissolved arsenic, boron, lithium, selenium, strontium, thallium, and vanadium using inductively coupled plasma-mass spectrometry: U.S. Geological Survey Open-File Report 99-093, 31 p., accessed February 27, 2021, at https://doi.org/10.3133/ofr9993.

Garbarino, J.R., Kanagy, L.K., and Cree, M.E., 2006, Determination of elements in natural-water, biota, sediment, and soil samples using collision/reaction cell inductively coupled plasma-mass spectrometry: U.S. Geological Survey Techniques and Methods, book 5, chap B1, 88 p.

Han, L.F., and Plummer, L.N., 2013, Revision of Fontes \& Garnier's model for the initial ${ }^{14} \mathrm{C}$ content of dissolved inorganic carbon used in groundwater dating: Chemical Geology, v. 351, p. 105-114, accessed February 27, 2021, at https://doi.org/10.1016/j.chemgeo.2013.05.011.

Han, L.F., and Plummer, L.N., 2016, A review of single sample-based models and other approaches for radiocarbon dating of dissolved inorganic carbon in groundwater: EarthScience Reviews, v. 152, p. 119-142, accessed February 27, 2021, at https://doi.org/10.1016/j.earscirev.2015.11.004. 
Han, L.F., Plummer, L.N., and Aggarwal, P., 2012, A graphical method to evaluate predominant geochemical processes occurring in groundwater systems for radiocarbon dating: Chemical Geology, v. 318-319, p. 88-112, accessed February 27, 2021, at https://doi.org/10.1016/j.chemgeo.2 012.05.004.

Hunt, A.G., 2015, Noble Gas Laboratory's standard operating procedures for the measurement of dissolved gas in water samples: U.S. Geological Survey Techniques and Methods, book 5, chap. A11, 22 p., accessed February 27, 2021, at https://doi.org/10.3133/tm5A11.

International Atomic Energy Agency, 2006, Use of chlorofluorocarbons in hydrology - A guidebook: Vienna, IAEA, 277 p., accessed February 27, 2021, at https://www.iaea.org/ publications/7187/use-of-chlorofluorocarbons-in-hydrology.

Lee, J.Y., and Hahn, J.S., 2006, Characterization of groundwater temperature obtained from the Korean national groundwater monitoring stations-Implications for heat pumps: Journal of Hydrology (Amsterdam), v. 329, no. 3-4, p. 514-526, accessed February 27, 2021, at https://doi.org/ 10.1016/j.jhydrol.2006.03.007.

Linhoff, B., Longmire, P., Rearick, M., McQuillan, D., and Perkins, G., 2016, Water quality and hydrogeochemistry of a basin and range watershed in a semi-arid region of northern New Mexico: Environmental Earth Sciences, v. 75 , article 640, p. 640, accessed February 27, 2021, at https://doi.org/10.1007/s12665-015-5179-8.

Lucas, L.L., and Unterweger, M.P., 2000, Comprehensive review and critical evaluation of the half-life of tritium: Journal of Research of the National Institute of Standards and Technology, v. 105, no. 4, p. 541-549.

Ludin, A., Wepperning, R., Bönisch, G., and Schlosser, P., 1997, Mass spectrometric measurement of helium isotopes and tritium in water samples: Palisades, New York, LamontDoherty Earth Observatory technical report, accessed February 27, 2021, at https://www.ldeo.columbia.edu/ sites/default/files/uploaded/image/Ludin_Lamond_Mass $\% 20$ spectrometric.pdf.

Manning, A.H., and Solomon, D.K., 2003, Using noble gases to investigate mountain-front recharge: Journal of Hydrology (Amsterdam), v. 275, no. 3-4, p. 194-207, accessed February 27, 2021, at https://doi.org/10.1016/ S0022-1694(03)00043-X.

Menció, A., Mas-Pla, J., Otero, N., Regàs, O., Boy-Roura, M., Puig, R., Bach, J., Domènech, C., Zamorano, M., Brusi, D., and Folch, A., 2016, Nitrate pollution of groundwater; all right..., but nothing else?: Science of the Total Environment, v. 539, p. 241-251, accessed February 27, 2021, at https://doi.org/10.1016/j.scitotenv.2015.08.151.
Meyer, H.W., 1992, Lapse rates and other variables applied to estimating paleoaltitudes from fossil floras: Palaeogeography, Palaeoclimatology, Palaeoecology, v. 99, no. 1-2, p. 71-99, accessed February 27, 2021, at https://doi.org/10.1016/0031-0182(92)90008-S.

Mueller, D.K., Schertz, T.L., Martin, J.D., and Sandstrom, M.W., 2015, Design, analysis, and interpretation of field quality-control data for water-sampling projects: U.S. Geological Survey Techniques and Methods, book 4, chap. C4, 54 p., accessed February 27, 2021, at https://doi.org/ $10.3133 / \mathrm{tm} 4 \mathrm{C} 4$

Myers, N.C., and Friesz, P.J., 2019, Hydrogeologic framework and delineation of transient areas contributing recharge and zones of contribution to selected wells in the upper Santa Fe Group aquifer, southeastern Albuquerque, New Mexico, 1900-2050: U.S. Geological Survey Scientific Investigations Report 2019-5052, 73 p., accessed February 27, 2021, at https://doi.org/10.3133/sir20195052.

Panno, S., Hackley, K., Hwang, H., Greenberg, S., Krapac, I., Landsberger, S., and O'Kelly, D., 2006, Characterization and identification of $\mathrm{Na}-\mathrm{Cl}$ sources in ground water: Ground Water, v. 44, no. 2, p. 176-187, accessed February 27, 2021, at https://doi.org/10.1111/j.1745-6584.2005.00127.x.

Parkhurst, D.L., and Charlton, S.R., 2008, NetpathXL—An Excel interface to the program NETPATH: U.S. Geological Survey Techniques and Methods, book 6, chap. A26, 11p., accessed February 27, 2021, at https://doi.org/ 10.3133/tm6A26.

Patton, C.J., and Kryskalla, J.R., 2011, Colorimetric determination of nitrate plus nitrite in water by enzymatic reduction, automated discrete analyzer methods: U.S. Geological Survey Techniques and Methods, book 5, chap. B8, 34 p., accessed February 27, 2021, at https://doi.org/ $10.3133 / \mathrm{tm} 5 \mathrm{~B} 8$.

Piper, A.M., 1944, A graphic procedure in the geochemical interpretation of water-analyses: Transactions American Geophysical Union, v. 25, no. 6, p. 914-928, accessed February 27, 2021, at https://doi.org/10.1029/ TR025i006p00914.

Plummer, L.N., Bexfield, L.M., Anderholm, S.K., Sanford, W.E., and Busenberg, E., 2004, Hydrochemical tracers in the Middle Rio Grande Basin, USA-1. Conceptualization of groundwater flow: Hydrogeology Journal, v. 12, no. 4, p. 359-388, accessed February 27, 2021, at https://doi.org/ 10.1007/s10040-004-0324-6. 
Plummer, L.N., Bexfield, L.M., Anderholm, S.K., Sanford, W.E., and Busenberg, E., 2012, Geochemical characterization of ground-water flow in the Santa Fe Group aquifer system, Middle Rio Grande Basin, New Mexico (ver. 1.2, November 20, 2012): U.S. Geological Survey WaterResources Investigations Report 03-4131, 395 p., accessed February 27, 2021, at https://doi.org/10.3133/wri034131.

Powell, R.I., and McKean, S.E., 2014, Estimated 2012 groundwater potentiometric surface and drawdown from predevelopment to 2012 in the Santa Fe Group aquifer system in the Albuquerque metropolitan area, central New Mexico: U.S. Geological Survey Scientific Investigation Map 3301, 1 sheet, scale 1:50,000, accessed February 27, 2021, at https://doi.org/10.3133/sim3301.

Révész, K., and Coplen, T.B., 2008a, Determination of the $\delta\left({ }^{2} \mathrm{H} /{ }^{1} \mathrm{H}\right)$ of water-RSIL lab code 1574 , in Révész, K., and Coplen, T.B., eds., Methods of the Reston Stable Isotope Laboratory: U.S. Geological Survey Techniques and Methods, book 10, chap. C1, 27 p., accessed February 27, 2021, at https://doi.org/10.3133/tm10C1.

Révész, K., and Coplen, T.B., 2008b, Determination of the $\delta\left({ }^{18} \mathrm{O} /{ }^{16} \mathrm{O}\right)$ of water-RSIL lab code 489 , in Révész, K., and Coplen, T.B., eds., Methods of the Reston Stable Isotope Laboratory, U.S. Geological Survey Techniques and Methods, book 10, chap. C2, accessed February 27, 2021, at https://doi.org/10.3133/tm10C2.

Rice, S.E., Oelsner, G.P., and Heywood, C.E., 2014, Simulated and measured water levels and estimated water-level changes in the Albuquerque area, central New Mexico, 1950-2012: U.S. Geological Survey Scientific Investigations Map 3305, 1 sheet, scale 1:50,000, accessed February 27, 2021, at https://doi.org/10.3133/sim3305.

Ritchie, A.B., Galanter, A.E., and Curry, L.T.S., 2019, Groundwater-level change for the periods 2002-8, 2008-12, and 2008-16 in the Santa Fe Group aquifer system in the Albuquerque area, central New Mexico: U.S. Geological Survey Scientific Investigations Map 3435, 1 sheet, 16-p. pamphlet, accessed February 27, 2021, at https://doi.org/ $10.3133 / \operatorname{sim} 3435$.

Roy, S., Gaillardet, J., and Allegre, C.J., 1999, Geochemistry of dissolved and suspended loads of the Seine River, France-Anthropogenic impact, carbonate and silicate weathering: Geochimica et Cosmochimica Acta, v. 63, no. 9, p. 1277-1292, accessed February 27, 2021, at https://doi.org/10.1016/S0016-7037(99)00099-X.

Rozanski, K., Araguás-Araguás, L., and Gonfiantini, R., 1993, Isotopic patterns in modern global precipitation: Geophysical Monograph, v. 78, p. 1-36, accessed February 27, 2021, at https://doi.org/10.1029/GM078p0001.
Thatcher, L.L., Janzer, V.J., and Edwards, K.W., 1977, Methods for determination of radioactive substances in water and fluvial sediments: U.S. Geological Survey Techniques of Water-Resources Investigations, book 5, chap. A5, accessed February 27, 2021, at https://doi.org/ 10.3133/ofr76560.

Thorn, C.R., McAda, D.P., and Kernodle, J.M., 1993, Geohydrologic framework and hydrologic conditions in the Albuquerque Basin, central New Mexico: U.S. Geological Survey Water-Resources Investigations Report 93-4149, 106 p., accessed February 27, 2021, at https://doi.org/ $10.3133 /$ wri934149.

Travis, R.E., and Myers, N.C., 2019, Hydraulic and waterquality indicators of aquifer zones contributing groundwater flow to wells in the Santa Fe Group aquifer system near southeast Albuquerque, New Mexico, 2013-16 (ver. 1.1, May 2019): U.S. Geological Survey Scientific Investigations Report 2018-5138, 21 p., accessed February 27, 2021, at https://doi.org/10.3133/sir20185138.

U.S. Air Force, 2011, Kirtland Air Force Base, NM, Bulk Fuel Facility spill assessment report: Report to Congressional Committees, March 2011, US House Rep 111-201, accessed February 20, 2020, at https:/www.env.nm.gov/wp-content/ uploads/sites/12/2019/10/KAFB_3-2011_Report_to Congressional_Committees.pdf.

U.S. Army Corps of Engineers [USACE], 2017, RCRA facility investigation report, Bulk Fuels Facility release, Solid Waste Management Unit ST-106/SS-111, Kirtland Air Force Base, Albuquerque, New Mexico: New Mexico Environment Department, prepared by Sundance Consulting, Inc., Albuquerque, N. Mex., accessed February 20, 2020, at https://hwbdocuments.env.nm.gov/ Kirtland\%20AFB/KAFB4479/KAFB4479.pdf.

U.S. Army Corps of Engineers [USACE], 2018, Kirtland Air Force Base quarterly monitoring report, OctoberDecember 2017 and annual report for 2017, Bulk Fuels Facility, Solid Waste Management Unit ST-106/SS-111: New Mexico Environment Department, prepared by EA Engineering Science and Technology, Inc.

U.S. Army Corps of Engineers [USACE], 2020, Kirtland Air Force Base quarterly monitoring report, April - June 2020, Bulk Fuels Facility, Solid Waste Management Unit ST-106/ SS-111: New Mexico Environment Department, prepared by EA Engineering Science and Technology, Inc.

U.S. Environmental Protection Agency [EPA], 2019, National Primary Drinking Water Regulations: EPA website, accessed September 19, 2019, at https://www.epa.gov/ ground-water-and-drinking-water/national-primarydrinking-water-regulations. 
U.S. Geological Survey [USGS], [variously dated], National field manual for the collection of water-quality data:

U.S. Geological Survey Techniques of Water-Resources Investigations, book 9, chap. A1-A10, accessed

February 27, 2021, at https://www.usgs.gov/mission-areas/ water-resources/science/national-field-manual-collectionwater-quality-data-nfm?qt-science_center_objects $=0 \# q t-$ science_center_objects.

U.S. Geological Survey [USGS], 2019, USGS Reston Groundwater Dating Laboratory-Analytical procedures for dissolved gases $\mathrm{N}_{2}$ / Ar: USGS web page, accessed September 9, 2019, at https://water.usgs.gov/lab/dissolvedgas/lab/analytical_procedures/.

U.S. Geological Survey [USGS], 2018, USGS water data for the Nation: U.S. Geological Survey National Water Information System database, accessed October 30, 2018, at https://doi.org/10.5066/F7P55KJN.

Weiss, R.F., 1968, Piggyback sampler for dissolved gas studies on sealed water samples: Deep-Sea Research and Oceanographic Abstracts, v. 15, no. 6, p. 695-699, accessed February 27, 2021, at https://doi.org/10.1016/00117471(68)90082-X.

White, W.M., 2013, Geochemistry: Hoboken, N.J., WileyBlackwell.

Zuber, A., Weise, S.M., Osenbruck, K., Grabczak, J., and Ciezkowski, W., 1995, Age and recharge area of thermal waters in Ladek Spa (Sudeten, Poland) deduced from environmental isotope and noble gas data: Journal of Hydrology (Amsterdam), v. 167, no. 1-4, p. 327-349, accessed February 27, 2021, at https://doi.org/10.1016/ 0022-1694(94)02587-2. 
For more information about this publication, contact

Director, New Mexico Water Science Center

U.S. Geological Survey

6700 Edith Blvd. NE

Albuquerque, NM 87113

For additional information, visit

https://www.usgs.gov/centers/nm-water

Publishing support provided by

Lafayette Publishing Service Center 

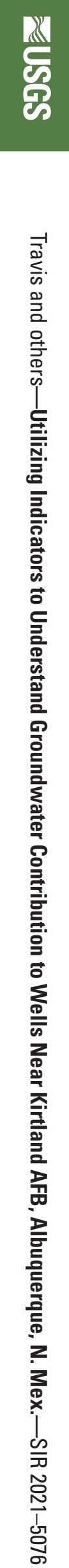